\title{
An Early Greek Epic
}

\section{Narrative Structures in Parmenides' Poem and the Relation between Its Main Parts}

\author{
Jaap Mansfeld \\ Department of Philosophy and Religious Studies, Utrecht University, \\ Utrecht, The Netherlands \\ j.mansfeld@uu.nl
}

Received October 2020 | Accepted November 2020

\begin{abstract}
The question (once again) is in what cognitively acceptable way the Alètheia and Doxa sections of the epic should be connected, that is to say in what way Parmenides himself may have envisaged the relation between ontological Truth and mistaken human Opinions. An important distinction is found to obtain between the common run of humankind, ignorant and helpless, and an enlightened human elite. The views of this elite serve as an intermediate between the cognitive condition of humanity in general and the arcane knowledge and ontology of the Alettheia section and help to attenuate the dualism by bridging the gap between ignorance and absolute Truth. There is a significant and crucial interplay between the two sections which works both ways, forward from the Alētheia to the Doxa section and backwards from the Doxa to the Alettheia section. Defining characteristics of the elements per se and of their compounds in the Doxa section are reflections of defining properties of Being in the Alētheia section. Conversely, recognition of these elemental characteristics may point the way back to properties of Being. The argument of the epic from fr. B1 to fr. B19 DK is strictly organized by means of reiterated theses and type-scenes, which lend an overarching unity to the poem. This technique itself is not new, but the contents of these reiterated motifs (such as the mention of humans, of the distinction between Being and not-Being, of name-giving, or of defining properties and characteristics) are original. The reiterated motifs which secure the proofs of the main thesis function as hidden persuaders. The story of the extraordinary journey of the anonymous author to the dwelling of his nameless goddess and the revelation he receives from her have been carefully authenticated and stage-managed to provide divine backing for the stunning doctrines put forward and are also aimed at convincing the audience.
\end{abstract}

(C) JAAP MANSFELD, 2020 | DOI:10.1163/1568525X-BJA10082

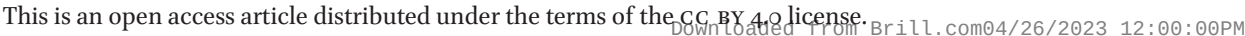




\section{Keywords}

didactic epic - adapted oral technique - narrative pattern - dualism - anthropological ingredients - Amēkhaniē - Anankē - personification - signs - resemblance macrocosm - microcosm - earth - moon - eye of the beholder - doxastic levels original philosophy of nature - name-labels - new myth - authentication - interlinked images - Phaethon - revisability - Hesiod - Anaximander - Heraclitus - Derveni Papyrus - Aristotle - Theophrastus - Descartes - Schopenhauer

It is of course well known that Parmenides' epic comprises two distinct main sections, or parts. The first part contains a deductive metaphysical system and presents the absolute Truth about a Being without beginning or end in time, which is single, indivisible, alone, homogeneous, complete, unmoved, unchanging, all alike unto itself and, last but not least, spherical, that is to say perfect. The second part contains a physical system according to flawed human Opinions: a deceptive cosmogony and cosmology based on a duality of elements, namely bright and light aetherial Fire (or Light) and dense, heavy and occult Night. The apparently watertight distinction between these two accounts, which approaches a strongly dualistic world-view, is explicitly stated in the pivotal passage of fragment 28B8.50-53 DK. Concluding her demonstration of the ontology, the goddess informs her exceptional visitor that 'at this point' ( $\dot{\varepsilon} \nu \tau \hat{\omega})$ she ends her account concerning the 'Truth', and that 'from this point on' ( $\dot{\alpha} \pi \dot{0} \tau 0 \hat{\delta} \delta \varepsilon)$ the views of humans will be the subject of her 'deceptive' exposition. ${ }^{1}$ For such a noteworthy transition from one important section to, and demarcation from, the next, marked in this explicit way, I have found no earlier parallels.

The key passage fr. 28B8.50-53 DK is part of what, borrowing Bruce Louden's terminology, I will call an 'extended narrative pattern', an 'organizing device', that is, consisting of 'recurring theses and type-scenes': a first intimation followed by a series of variously formulated recurrent explicitations, which lend an overarching unity to an epic poem. Though this technique must have been

1 Paralleled fr. B19.2, $\dot{\alpha} \pi \dot{\partial} \tau 0 \hat{\delta} \varepsilon$, 'from now on'; other parallels of this phrase are only found in

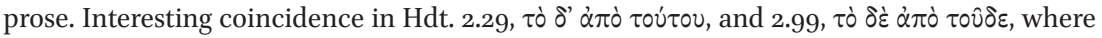
both times what follows is said by the author to be less secure than what came before. On truth and fiction sharing a platform see Finkelberg 1998, 158-16o and 168-169, and Heiden 2007 on fiction close to truth (he does not refer to Parmenides). 
used and developed by poets working in an oral tradition that goes back a long way, we will do well to keep in mind that our evidence for ancient Greece is exclusively of a written nature. ${ }^{2}$ It was also used by poets who performed their own works. Parmenides adapted and developed the technique further. As far as I know its relevance for the interpretation of his epic has been considered only marginally or suggested in general terms; ${ }^{3}$ the work of Xavier Gheerbrant is an exception. ${ }^{4}$ Looking at other representatives of early epic poetry helps to

2 Louden 1993, 5-33, cited from ch. 2 of Louden 1999; see also Buglass, Fanti, and Galzerano 2019, 247-254: "didactic-epic formulas", and 253-257: "type-scenes from epic to didactic" (but not p. 233 on Parmenides). For Louden's similar analysis of the Iliad see his book of 20o6, esp. the 'Introduction', 1-13, and ch. 1, 'The principal narrative pattern', 14-52. Di Benedetto 1994, $177-238$ on 'Correspondenze a distanza e l'organizzazione del racconto' in the Iliad is still quite useful. For a somewhat different type of structuring device in the Homeric poems see Van Otterlo 1944, and for its presence in Empedocles Santoro 2013, who speaks of rondeaux, a literary term, and ritornell(o), originally a musical term; Gheerbrant 2018, too, uses ritornell. Santoro does not show in what way such iterations structure the physical poem as a whole, which is what Gheerbrant does. Kranz 1916, who had to manage without the support of narratology or theories about orality and performance, already provides a quite helpful analysis of the poem's structure.

3 Observations on poetry and repetitions are found in the indispensable overview of scholarship on Parmenides of' Kraus 2013, 447-448. Toohey 1996, 34, who emphasizes the traditional background, focuses on the oral relation between instructor and addressee and points at the absence of "formulaic material" in fr. B8. On "verbal rings and repetitions" in Parmenides' proem see Strauss Clay 2015, 120-122; on ring composition and verbal echoes in the proem Hülsz and Berruecos 2018, who follow Kurfess 2012, 43-50, and on rhetorical figures in the proem Mansfeld 1994. Repetitions are turned into incantations in Kingsley 1999, 136-140, followed by Gemelli Marciano 2013, 58-59 and passim. "Parmenides' poem is a sacred text", we read at Kingsley 2003, 199, which comes close to mystiquerie. Note that Kingsley only adverts

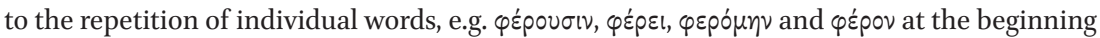
of the proem-no eye for recurring theses and type-scenes. On Kingsley's manipulation of the evidence see Bremmer 2018; a striking example is his proposal 2003, 126-156, to change fr. B $7.5 \lambda \hat{o}^{\prime} \boldsymbol{\omega}$ to $\lambda \dot{6} \gamma \mathrm{ov}$, which effectively gets rid of human critical judgement. He is followed by Gemelli Marciano 2013, 87-89. $\lambda$ órov in the innocuous sense these scholars need is superfluous in view of $\dot{\xi} \xi \xi \mu \varepsilon \dot{\varepsilon} \theta \varepsilon \dot{p} \dot{\eta} \theta \varepsilon v \tau \alpha$ in the next line. This has been believed to be the first occurrence of the word $\lambda$ ó $\gamma$ s in the sense of 'argument' or 'reasoning', but the 'gentle words'

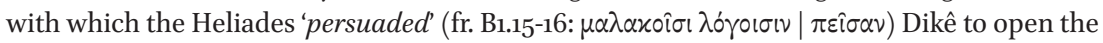

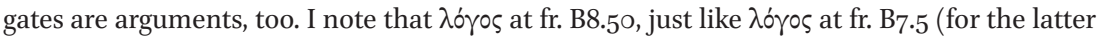
see e.g. Gianvittorio 2013, 12 with references) most of the time translated as 'discourse', is translated as 'argument' by Laks and Most 2016, vol. 5, 51.

4 On March 29 2019, at the 'Conference on Orality and Literacy XIII: Repetition' held at the University of Austin, Gheerbrant read a paper entitled 'Repetition in early Greek philosophical poetry' which has not yet been published and of which, as he tells me per litt., the section on Parmenides, focusing on the proem, will eventually be published separately. In the online abstract he writes: "In Parmenides, repetition has two main functions: structuring the poetic material within each part of the poem (the proem, the part on Being, and that on the world), and reflecting on the relationship between those parts." I couldn't agree more. 
understand what Parmenides is doing, but this should also be clear without this background.

Parmenides' poem in dactylic hexameters is the earliest relatively wellpreserved epic poem that is later than some of the larger Homeric hymns and the Hesiodic Scutum. ${ }^{5}$ No less than 155 lines are extant, including a few halflines, and six lines in Latin translation. This may amount to from one fifth to one fourth of the entire work. ${ }^{6}$ I am not saying, of course, that Parmenides is an oral poet, ${ }^{7}$ but contend that not only, as has been seen, much of his vocabulary and phraseology, ${ }^{8}$ but also most of his expository technique-perhaps principally as a form of hidden persuasion - is indebted to the Panhellenic tradition of the epic poetry he and his audience knew, remembered, and shared. In other words, this is an epic dressed in familiar cultural garb, presenting a cosmogony and a cosmology like Hesiod's Theogony and Orphic literature, though in an uncommon and original way. ${ }^{9}$ Cicero, either quoting an ancient critic

5 In his overview of the chronology of early epic poetry West 2006, 240 dates the work of Parmenides to са. 49 о вСЕ. Of the Cypria no more than 53 lines are extant.

6 The verbatim frs. B 7.1-2 and 7.2-7a, B8.38 and 43-45, B13 (one line) and B16 (four lines), i.e. sixteen lines out of a total of 155 , are already quoted by Plato, Aristotle and Theophrastus. For our ancient sources of information see Kraus 2013, 441-442.

7 Hershbell 1968, 353 n. 19 briefly adverts to "metrical regularity" and "what seems to be the repetition of ideas" (which apparently he sees as padding) and is followed by Kołakowska 2017; Hershbell suggests that the "possibility exists" that Parmenides was "an oral poet". For Toohey 1996 see above, n. 3. Cerri 1999b, 12-13, on the other hand, insists that Parmenides had to develop a novel style and technique. Bollack 20o6a shows that Parmenides used earlier forms to give weight to his novel project. Atwood Wilkinson 20o9, who emphasizes the oral background, does not venture beyond performance and vocabulary (cf. next note). For Parmenides' हैं $\eta$ or $\pi$ oเ $\mu \alpha \tau \alpha$ see e.g. D.L. 9.22 (fr. A1) and 8.55 (fr. A9), and below n. 10.

8 See e.g. Coxon 1986, 7-11 = 2009, 7-12 and his first apparatus, and the convenient lists at Mourelatos 2008, 8-10. Wöhrle 1993 argues that Parmenides adapted Homeric language to a new purpose. A couple of significant words occur for the first time in Parmenides, namely

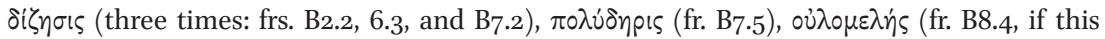

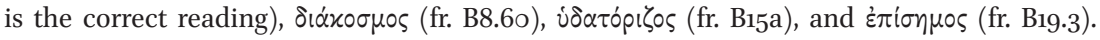
$\pi \circ \lambda \dot{\delta} \eta p ı \varsigma$ and $v \delta \alpha \tau o ́ p p i \zeta o \varsigma ~ a p p e a r$ to be hapax legomena.

9 López-Ruiz 2016, in the section subheaded 'Other archaic and classical cosmogonies', representing what seems to be a fairly common view, writes "[o]utside the Hesiodic and Orphic traditions, there is little interest in cosmogony as a genre (the genre was more popular in the Near East)", which is to overlook Xenophanes, Parmenides and Empedocles. Theogony was also mostly absent in early mythography. The Pythagorean Orphica are dated by West 2006, 240 to ca. 510 and the Orphic Theogony to ca. 500 BCE, so a little before Parmenides (cf. above, 
or (perhaps less likely) judging for himself, saw him as a mediocre poet, but as a poet nevertheless (his 'verse is not so very good, though it is still verse'). He ranks Xenophanes ${ }^{10}$ and Parmenides far below Empedocles in this respect. ${ }^{11}$

Though the proem and the large fr. B8 together contain about two thirds of these 155 lines, the distribution of the remaining third of the material over the remains of the epic as a whole, before the large fr. B8 and following on after this fragment, provides sufficient room for anticipations and repetitions of this kind. ${ }^{12}$ This extended pattern includes not only recurring theses, as is to be expected in a philosophical text, but also typical scenes, because of Parmenides' dramatic presentation, figuring an actual teacher, who again and again addresses an actual disciple,$^{13}$ as well as other human and divine agents. It should be set out at greater length than is possible now, analyzing not only similarities but also differences in more detail. Repetitio est mater memoriae: in a didactic epic such a thematic pattern is perhaps even more apropos than in a poem belonging to the Theban or Trojan cycle. ${ }^{14}$

n. 5). But this is uncertain, for most scholars date the early Orphica much earlier, while (as Jan Bremmer points out to me) they may even be a little later than Parmenides.

Parmenides wrote 'in hexameters' ( $(\dot{\varepsilon} \nu$ है $\pi \varepsilon \sigma$, Thphr. fr. 227 B FHS\&G at D.L. $8.55=$ fr. 28 A9 DK, cf. Diels in the apparatus at Thphr. Phys.Op. fr. 3). Xenophanes inter alia also 'wrote in hexameters'. His extant remains, like those of Parmenides, bear this out, cf. frs. 21B23, ${ }_{21} \mathrm{~B}_{34}$, and on cosmological subjects frs. $21 \mathrm{~B} 27-33 \mathrm{DK}$. He reportedly 'recited his own poems', so was both a writer and an oral performer (fr. 21A9 DK at D.L. $9.18 \gamma \varepsilon$ ₹ $\gamma \alpha \varphi \varepsilon \delta \dot{\varepsilon} \dot{\varepsilon} \nu$

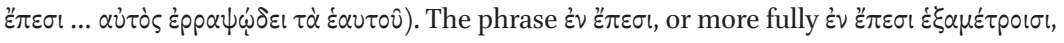

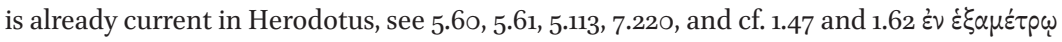
$\tau o ́ v \omega$.

11 Cic. Luc. 74: minus bonis quamquam versibus, sed tamen ... versibus, Xenoph. fr. 21A25 DK, not cited in the Parmenides and Empedocles chapters. For praise for Empedocles see Cic. De orat. 1.217 (fr. $31 \mathrm{~A} 25$ DK), Empedocles poeta egregium poema fecerit. On the issue see Wöhrle 1993, cited above n. 8, and the measured appraisal of Floyd 1992. Calame 2013 somewhat overstates Parmenides' poetic status.

12 It will be clear that like most scholars I accept the by now traditional order of the B-fragments as in DK only slightly modified e.g. in Coxon 1986 and Laks and Most 2016, vol. 5 , and have not been convinced by the argument of Cordero 2010 that this should be revised. The attempt by Kurfess 2012 to rehabilitate Sextus' cento of the proem and lines further down in the poem, with unhelpful consequences for the order of fragments, has been refuted by Cordero 2016.

13 Emphasized by Kranz 1967, $136(=1916,1168)$, and standard procedure in didactic litera-

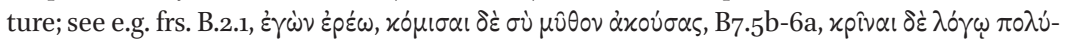

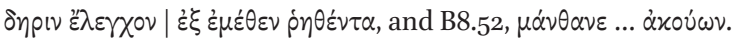

14 Osborne 1998 and Vesperini 2015 claim that 'didactic poetry' is not recognized as a genre in antiquity. Our explicit evidence in fact is rather late. Poll. Onom. 1.30.1-3 states that 'the didactic genre is dry and tedious', so it will do no harm to add 'the grace of a myth in

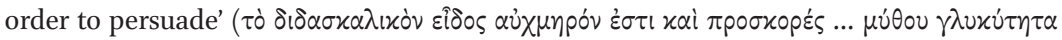

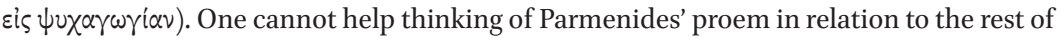


The first occurrence of an element of the extended pattern, mentioning humans, is in the proem. The goddess, welcoming her visitor, notes that he

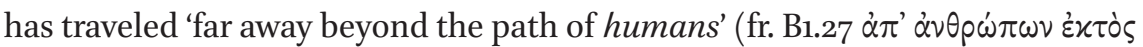
$\pi \dot{\alpha} \tau 0 u)$. This is continued in the second occurrence, immediately following in the proem, as the goddess tells him that he will be informed 'both of the unmoved heart of well-rounded Truth, and of the Opinions of mortals ( $\beta$ po$\tau \hat{\omega} \nu \delta \delta$ ' $\alpha \varsigma$ ), in which there is no true trust' (fr. B1.28-30), briefly foreshadowing the contents of both main parts of the epic. (The epithet 'well-rounded', curxv$x \lambda \varepsilon \dot{\varepsilon} \circ$, anticipates the sphericity in which the description of Being culminates at fr. B8.42-49 and contributes to the pattern). ${ }^{15}$ The third occurrence is in

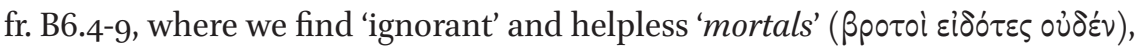
'deaf as well as blind', who are 'in a state of perplexity' ( $\alpha \mu \eta \chi \alpha v$ in). As we shall see below, these mortals belong to a different category than the name-giving mortals subsequently mentioned twice in the large fr. B8 (lines 38-41 and 51-59) and once in the concluding line at fr. B19.3. We are told that for these ignorant people of fr. B6 'to be and not to be are the same and not the same', a confusion which makes their quandary the contrary of the correct ontological stance of frs. B2 and B8; a stance, again, that had been briefly summarized at the beginning of this same fr. B6, lines 1-2. A related passage (I give it the number 3a) is at $\mathrm{fr}_{\mathrm{B}} \mathrm{B}$, where the visitor is advised to keep his distance from the means of information and the talk of these unseeing and unhearing people, and to turn instead to the 'refutation' (' tion provided by the goddess (as in fr. B2 and elsewhere). As a matter of fact, the crucial distinction between Being and not-Being, argued in some detail in fr. B2, is repeated no less than three times later on, namely in frs. B6.1-2, B7.1-2

the poem. [Lib.] Characteres epistolici, Prol. b4 mentions the 'didactic letter by means of

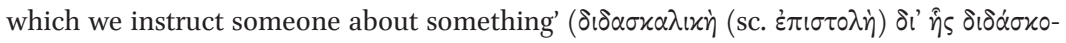
$\mu \varepsilon^{\prime} v \tau i v \alpha \pi \varepsilon p i \tau i v \circ \varsigma$ ). The Scholia vetera in Opera et dies begin by stating that Hesiod takes

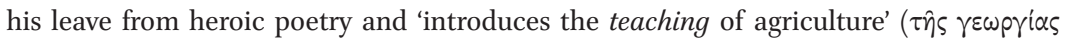

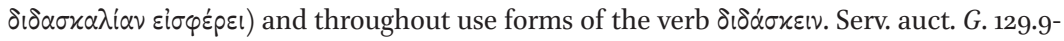
11 Thilo-Hagen tells us (see Schiesaro, Mitsis, and Strauss Clay 1994, 9) that hi libri (sc. Georgica) didascalici sunt, unde necesse est, ut ad aliquem scribantur; nam praeceptum et doctoris et discipuli erequirit: unde ad Maecenatem scribit (sc. Vergil), sicut Hesiodus ad Persen, Lucretius ad Memmium.

15 It is rejected by numerous scholars in favour of the at first sight easier varia lectio $\varepsilon \dot{\pi \varepsilon l-}$ Өćos, 'convincing', but see e.g. Mansfeld 1995, 232 = 2018, 48-5o, and now Jackson Rova 2020. Simplicius, who (pace Kurfess 2014) unlike others quotes a text of Parmenides'

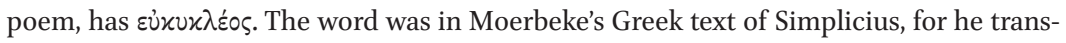
lates (bold added) veritatis circularis intrepida anima, quoted Mansfeld 1995, 231 = 2018, 48 n. 34 and Kraus 2018, 222. 
and B8.15-18, and qua organizational device strengthens the unity of the ontology of the first section of the epic.

The fourth occurrence of an anthropological ingredient is in fr. B8.38-41, ${ }^{16}$ where the deduction of such properties of Being as 'without beginning or end' and 'without motion' is interrupted by a critical note concerned with 'names

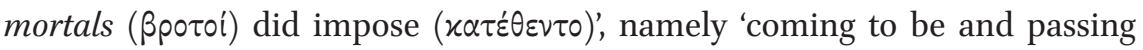
away, being as well as not-being' (so distinguishing between them and not confusing them as the mortals of fr. B6.2-5), 'changing place and altering bright colour'. This remark about the names 'changing place' and 'altering bright colour', rather enigmatic in its actual context, preludes upon the cosmology of the Doxa section of the epic. ${ }^{17}$ The fifth occurrence is at the pivotal passage at the end of fr. B8, lines 5o-61, where the account of Truth ends, the Doxa section begins, and the names-imposing mortals - the implied subject of (again)

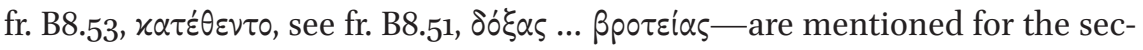
ond time. Their mistake, from which everything else follows, is that they name two Shapes, ${ }^{18}$ which sets up a kind of dualism, contrasting with the monism of Being. ${ }^{19}$ The sixth occurrence is at fr. Bg.1, where we hear that 'everything has been named Light and Night'-by humans, of course. Humans ( $\alpha \nu \theta \rho \omega \dot{\pi} \pi \circ \sigma \iota)$ are mentioned for the seventh time in fr. B16, where the physical basis of their cognitive activity is explained. The eighth occurrence is the passage at the end

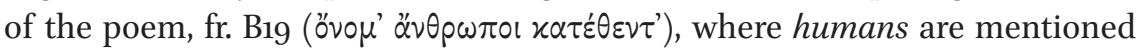
for the eighth time, and their name-giving activities for the fourth. Frappez toujours. There may have been more instances, but as most of the Doxa part is lost we cannot know. ${ }^{20}$

16 The transposition of lines fr. B8.34-41 to a position after B8.52 (according to the present numeration) argued by Ebert 1989, not unattractive at first sight, damages the pattern by taking out its fourth occurrence.

17 'Altering bright colour' from day to night and back or in the course of the month (the phases, हैpra, fr. B10.4, of the moon, cf. Conche 1996, 207), 'changing place' like sun and moon and stars. Cf. Mansfeld 2005, $558=2018,182-183$.

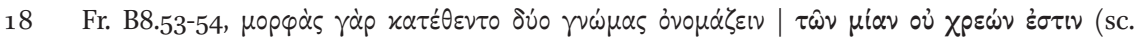

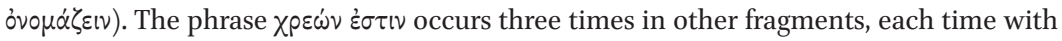

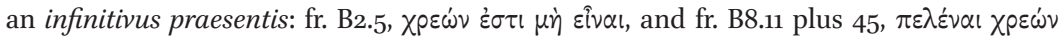

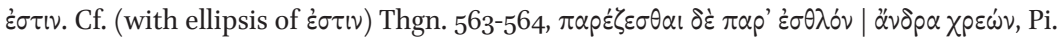

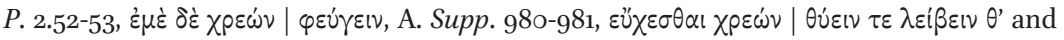

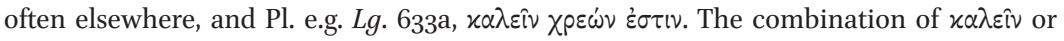

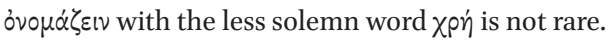

19 In the present inquiry I am not concerned with the standard division of the elements according to number. For an account of elemental dualism in Parmenides see e.g. Journée 2015, esp. 127-131.

20 This structuring technique is of course not restricted to the traditions of poetry influenced by oral composition and recitation, or to antiquity, or to serious literature. For 
I assume that the words $\ddot{\alpha} \nu \theta \rho \omega \pi 0$ l and $\beta p o \tau o$ ire used interchangeably (perhaps metri causa), as generally in early epic poetry. And step by step, from the intentionally obscure proem to the closure of the poem, matters gradually become clearer as the story unfolds. As a matter of fact, as one hears or reads the epic for a second or third time, obscure or succinct passages will be gradually filled with more meaning. It is nevertheless not so easy to determine the relation and interaction between metaphysics and physics, let alone to find such links as may be argued or believed to be convincing. This was already noticed by the philosophers of the next generations, who were decisively influenced by Parmenides. Zeno and Melissus, in their different ways, stuck to metaphysics and abandoned physics. Protagoras appears to have criticized the ontology, and Gorgias composed a parody. Empedocles, Anaxagoras, and the early Atomists, on the other hand, fitting out their various elements and the totality of things with selected properties of Parmenides' Being, encapsulated parts of the metaphysics within their physical systems. Alcmaeon, writing like Parmenides not only on the heavenly bodies but also, and in more (extant) detail, on human physiology and cognition, does not seem to have been concerned with ontological issues. For Plato, much later, Parmenides is again the philosopher who, like Melissus, posited a 'sole and unmoved All' (Tht. 180e); no discussion of the cosmology. ${ }^{21}$

Nevertheless, it may be worth our while to try and find out in what way Parmenides himself may have envisaged the relation and interaction between ontological Truth and mistaken human Opinions to be. ${ }^{22}$

Returning to Parmenides' humans, we should recall the two different groups mentioned above. The first group, in fr. B6, are said to be 'mortals who know

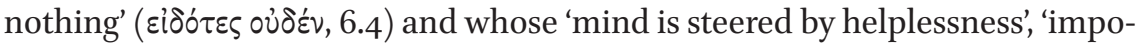

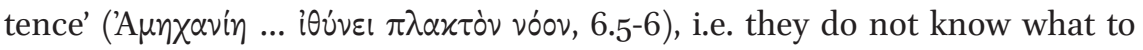

Goethe's use of it in Faust see the commentary of Schöne 1994, 48-53. But we may also for instance think of the familiar typical scenes in the Sherlock Holmes stories of Conan Doyle, or in the series of Maigret novels of Simenon, or of the serial elements in television series.

21 Mansfeld 2019, 1-4.

22 In his interesting study of esp. the second part of the epic Rossetti 2017 perhaps pays insufficient attention to this aspect of the issue, while in his study of 2010 he argues that the second main section of the poem contains the sort of knowledge Parmenides had attained during a 'precritical stage' of his research. 
do or believe. 'Steered by helplessness' is a nice paradox. The mind as bateau ivre... In view of Parmenides' focus on female divine forces (think of Themis, the spouse of Zeus, and his daughter Dikē, both figuring in the proem at respectively fr. B1.32 and B1.14-16 and 32, of Moira in the proem at B1.27 and in fr. B8.37, of Anankē in B.8.35-36, and B8.42-43, and in the Doxa section at B10.57), I believe that in the text of Parmenides we should write the word 'A $\mu \eta \chi \alpha v^{\prime}$ ' with a capital A. In Alcaeus fr. 364 Lobel-Page and Herodotus 8.111.13-15 'A $\mu \alpha \chi \alpha v i \alpha / A \mu \eta \chi \alpha v i \alpha$ is a divine personification, mentioned together with her sister 'Poverty' (П飞vi $\alpha) \cdot{ }^{23} \mathrm{~A}$ divine personification with a similar function and mortals in a similar condition are found in the Pindar fragment quoted by Plato in Book 1 of the Politeia: 'Hope, who chiefly steers the ever-twisting mind

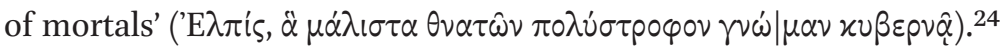

The second group are said to have 'imposed names on' (fr. B8.38-41, $\pi \alpha \dot{v} \tau$ '

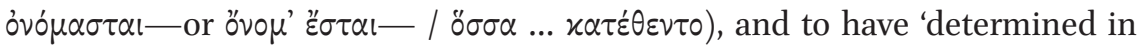

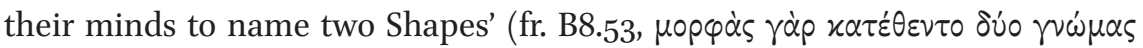
ovo $\dot{\alpha}^{\prime} \zeta \varepsilon(v),{ }^{25}$ so they certainly believed they knew what they wanted, although, as the goddess adds, they were mistaken. There is a substantial difference

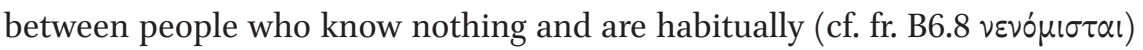
at a loss what to do or to believe, and people who are in the possession of

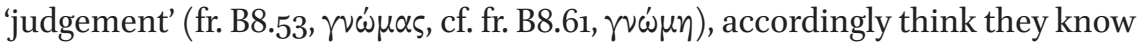
what to believe and how to act, are therefore capable of giving names to two Shapes. And subsequently even to particular things, as appears from frs. B.9.2

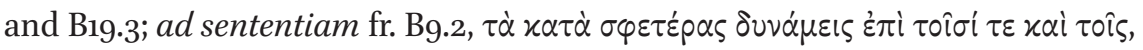
'according to their own ${ }^{26}$ powers' [i.e. qualities] 'to these and those (things)', is

23 Cited Shapiro 1993, 188-189. The verb i $\theta$ v́vıv is also used elsewhere with divinities as subject. Also cf. Ov. Tr. 5.14.29, rara quidem virtus, quem non Fortuna gubernet. Martin $1983,43-58$ in his study of amēchania with the heading 'Helplessness in the language of lyric and tragedy', is concerned with ways to escape this condition; he has overlooked the Alcaeus passage and the occurrences in the Theognidea quoted below. On personification of esp. abstract feminine nouns see Burkert 2005 and 2011, 283-285 = Engl. trans., 184186, with references; for Parmenides see Northrup 1980, and below, text to n. 83. Coxon 1986, $168=2009,262$ refuses to think of personification in the case of Themis and Dikē at fr. B1.28. Galgano 2016 concentrates on amēchania as the opposite of the mêchane (a word not present in the poem) which, he argues, is offered by the doctrine of fr. B2. This is too restricted.

24 Pi. fr. 214.3-4 Maehler at Pl. R. 331a. Maehler writes 'E $\lambda \pi$ i $\varsigma$ with a capital E, editors of the Politeia do not.

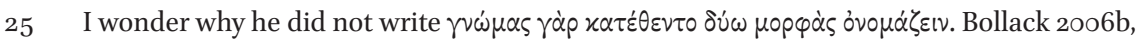
208-210 argues that one can only give names after distinguishing the forms, so one should translate 'Car ils ont posé des formes pour donner nom à deux principes'. I owe this reference to Xavier Gheerbrant.

26 'Their own', i.e. of these individual entities, not 'their' which could refer to the Shapes. 


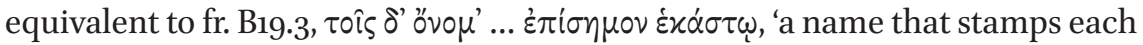
individual thing': another recurring thesis, one enclosing the Doxa section. The moon, for instance, is called 'fire' as well as 'night' insofar as it is a compound of these elements, but is also called with the further name-label 'moon' to indicate the particular nature of this blend, denser and thus colder than that of

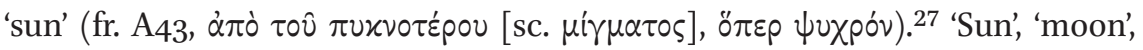
'heaven', 'stars', 'human', and so on are 'additional' ('̇ $\pi$ i-) name-labels that are stamped upon, given to, parts or compounds of the primary names 'fire' and 'night', just as pictures and inscriptions are stamped on pieces of metal to turn them into identifiable coins of a certain value.

Identifying the two categories of humans (as is generally done, and as I have till now always done myself) should be avoided. ${ }^{28}$ The way of the igno-

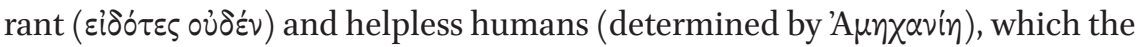
poet is urged to avoid in both fr. B6.3 and fr. B7.2-5a, ${ }^{29}$ cannot pertain to the cosmology of the Doxa part. Quite the contrary, for according to the proem (fr. B1.31-32) he is obliged to learn that the Opinions of humans may to a certain extent be justified and accepted.

These name-giving humans are an intellectual elite. Explicit parallels for this mindset are for example found in Parmenides' contemporary Heraclitus, who sharply distinguishes the ignorant 'many' or 'majority' (oi $\pi 0 \lambda$ oí, oi $\pi \lambda \varepsilon \hat{\sigma} \sigma \tau \circ \mathrm{l}$ ), or 'the crowd' (ö $\mu 1 \lambda \circ \varsigma)$, incapable of grasping the truth or what is best and satiating themselves like 'cattle' ( $\varkappa \tau \eta \dot{\nu} \nu \varepsilon \alpha)$, from 'the few' who are 'good' (o $\lambda$ irol $\delta \dot{\varepsilon}$

27 For these compounds see below, n. 60 and text thereto, and for the origin of language by

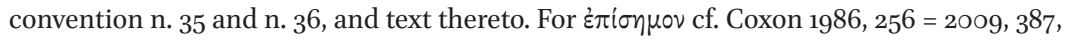
and Conche 1996, 268.

28 For the identification, which apparently goes back to an apodictic utterance of Reinhardt 1916, 68-69 = trans. 1993, 302-303, see e.g. the otherwise interesting account of Nightingale 2007,190 . Tor 2017,198 explicitly states that "the goddess nowhere qualifies her recurrent references to 'mortals", adding that her "remarks in fr. B6.4-6 refer to mortals in quite a general way and not to some very particular, small subset of mortals". But a subset is at issue elsewhere in the poem, see below, n. 33 and text thereto. Even Johansen 2016, 11 believes that "[i]n B 8.53-59 the goddess returns to this third way", i.e. to the position of the humans described in frs. B6 and $\mathrm{B} 7$, which ibid. p. 10 he characterizes as one of "general confusion". But he is aware of the difficulties involved, for he surmises that notwithstanding this confusion "[t]here may well be a way of understanding a route that combines what is and what is not in a way that does not involve one in a double self-contradiction". He also points out, ibid. p. 11, that "no mortal 'knowing nothing' could devise or appreciate this kind of account", i.e. the cosmology of the second part. Kranz 1967, 133 (= 1916, 1165) speaks of the "Fehler gewisser Menschen". Cf. also below, n. 37 .

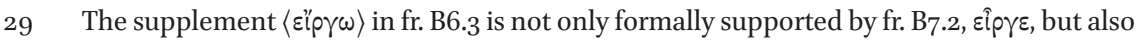
ad sententiam by the exhortation at B7.3-5a to 'avoid employing the aimless eye and echoing ear and tongue'. 


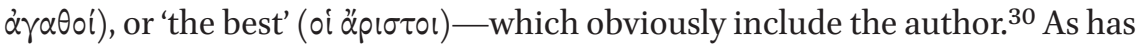
long been seen, Parmenides, an author who right at the beginning presents

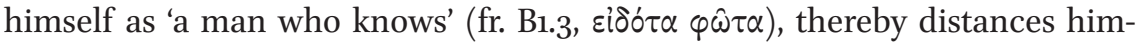
self from those 'who know nothing. We know that he was a member of the Ouliad family, important enough to be commemorated much later in inscriptions of the first cent CE excavated in Ascea. ${ }^{31}$ One is tempted to translate 'an intellectual'... ${ }^{32}$ Being a poet already qualifies a person for this predicate. The report that he 'served his native city as a legislator' (D.L. 9.23 = fr. A1, trans. Hicks, $L C L)$ shows that he was considered an important citizen, which is what Plutarch (Against Colotes 1226A = fr. A12) in fact tells us.

I have long believed, and am not alone, that what we find in fragment B6 is not just a piece of polemics with another philosopher, ${ }^{33}$ but a philosophically far more interesting description of the human condition in traditional terms, part and parcel of the social or cultural memory of the intended audience. Parmenides' and Heraclitus' unflattering opinion of the common run of humankind is anticipated in characterisations of humanity in general in earlier literature. Parallels are numerous, for instance the words $\alpha \mu \eta \chi \alpha v_{i n}$

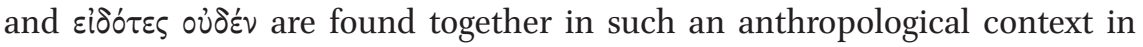
the Theognidea, lines 139-140. The word $\alpha \mu \eta x \alpha v i \eta$ is in fact a favourite in this

$30 \quad$ Quoted from frs. 22B2, B29, B57 and B101 DK. The logos of Bias son of Teutames is worth more than that of 'the others' (fr. 22B39), doubtless because of his maxim 'most people

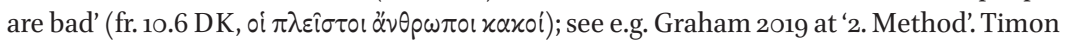

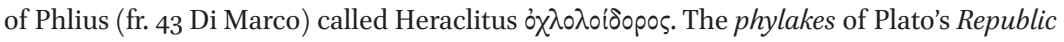
are a later example of an elite of this kind. With virtually Heraclitean panache the author of the Derveni papyrus, implicitly recommending his own exegesis, distances himself in

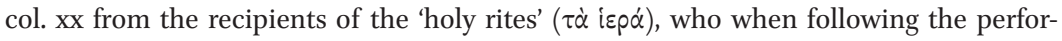
mance see the drōmena and hear the legomena but 'do not understand' them ( $\mu \grave{\eta} \gamma(\underline{v} \omega$ ' $\sigma \kappa \varepsilon i v$, trans. Laks and Most 2016, vol. 6, 419), and from those who perform the drōmena and recite the legomena without being able to explain their deeper meaning; see further Jourdan 2003, 87-88; Piano 2016, 108-109; and Kotwick 2017, 43, 55, 59. For the elite audience of the Derveni papyrus see Scodel 2011, 94, and for elites in the archaic polis see Ma 2016, and in the context of archaic poetry Kurke 2007.

31 First published about sixty years ago. One of them (SEG 28.1020) mentions 'Parmenides,

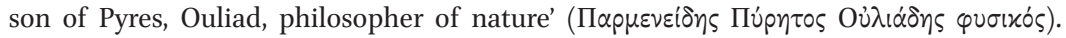
Accessible e.g. as Laks and Most 2016, vol. 5, Parmenides fr. P23a. Other inscriptions found at the same site mention other members of the family.

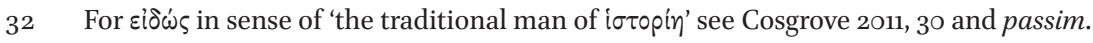

33 Mansfeld 1964, ch. 1, 'Die Vorgeschichte des dritten Weges', 1-41, where more passages are cited. The only small (but insufficient) point in favour of the identification of these mortals with Heraclitus is that they cannot be identified with those of fr. B8.51-59, for Heraclitus is not concerned with giving names to things, or with self-identical elements. Frère 2012 believes that Heraclitus is meant at fr. $\mathrm{B}_{7}$ and resuscitates the unlikely Pythagoreans at fr. B8.51-59. For Tor 2017 on fr. B6 see above, n. 28. 
collection, occurring no less than nine times. The earlier poet Semonides,

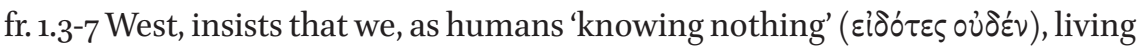

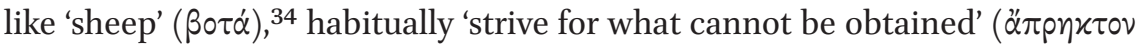

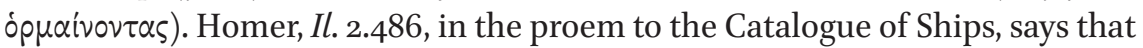

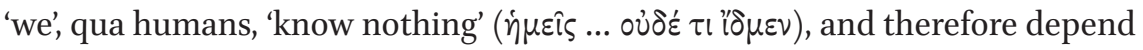
on information given by the Muses to the poet, who is someone cognitively privileged over other men. And so on. The mortals of fr. B6 recall the humans of this pessimistic and self-denigrating tradition.

But as far as I know there are no parallels in Greek literature earlier than Parmenides for a doctrine pertaining to human beings who gave names to things; not only to their basic elements, but also to things in general. These people invented, and developed, language. It is only in later literature, mostly

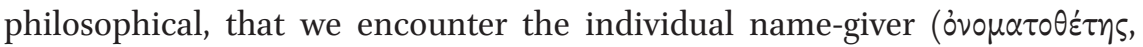

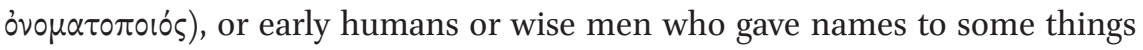
or to things in general. So it appears that Parmenides must be credited with a pioneering view of the origin of language by convention..$^{35}$ Presumably, this is also meant to counter the etymologizing of names found in early Greek poetry, which reflect the custom of recognizing a newborn infant by giving it a descriptive or otherwise meaningful name. ${ }^{36}$

34 A metaphor anticipating the 'cattle' of Heraclitus fr. B29 cited above.

35 Burkert 1970, 351 points out that "le nom, bien qu'il soit privé de réalité, obtient chez Parménide une importance plus grande que jamais, comme constituant du monde dans lequel nous nous trouvons" (it will become clear that I cannot share the qualifation

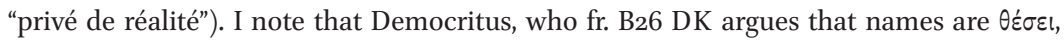

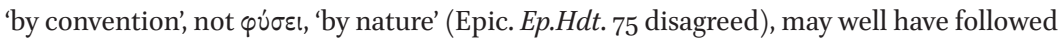
Parmenides in this respect, like he did in others.

36 The origin of language is not a theme in early Greek myth. On early etymologizing and names given to infants see Gambara 1989, 81-82 (for an example, Od. 19.409, see below, n. 49) and Desbordes 1989, 152-154. The Pythagorean akousma on the 'name-giver (or: what gives names) as being the second best wisest' cited by two late authors, namely

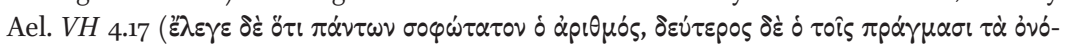

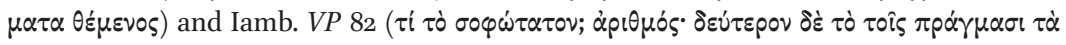
ovó $\mu \alpha \tau \alpha \tau(\theta \varepsilon \dot{\mu} \mu \varepsilon \vee 0 v)$, often believed to be early because belonging to the archaic category

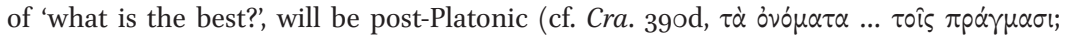

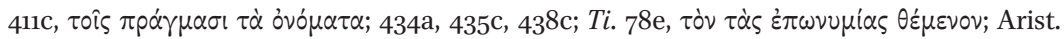
Cael. 27ob16-24, Mete. 379b14). Cordero 2019, 13-16 suggests that in some way or other the Pythagoreans are involved. Anyhow the akousma is hardly concerned with the origin of language in general. Pythagoras was later credited with the invention of particular

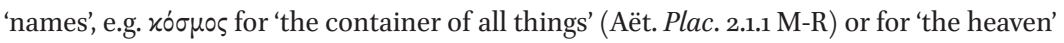
(Anon. Diod. 240.3, cf. D.L. 8.48), and $\varphi$ i $\lambda \circ \sigma \circ \varphi$ í $\alpha$ for his own occupation (Heraclides fr. 86 W. at D.L. prooem. 12, Anon. Diod. 223.29). Accounts of the origin of language are found in Kultur-Entstehungslehren (Protagoras in Pl. Prt. 332a, Epicurus, Lucretius, Diodorus, Vitruvius), and are presupposed in the Cratylus. See e.g. Spoerri 1959, IIB: 'Die Entstehung 
It is clear that humans who know nothing and do not know what to do are at a greater distance from the World of Truth than those who, however mistaken, at least are capable of setting their minds to the naming of elements (fr. B8.53-59) and things in general (frs. B9.1-2 and B19.3). In the former case there is no even remotely positive contact with the World of Truth. ${ }^{37}$

Aristotle was not entirely wrong when he stated that Fire and Night (or the 'hot' and the 'cold', as he called them) may be ranged with, respectively, Being and not-Being. ${ }^{38}$ That Night ( $\nu \dot{x} x \tau^{\prime} \alpha \dot{\delta} \alpha \hat{\eta}$, fr. B8.59) is called 'unknowing', opaque, 'dark' to some extent indeed recalls the characterization of not-

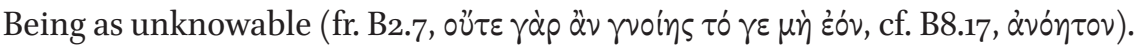
Arguing from there that Light should be ranged with Being is not illogical, although there is nothing in the description of Light as 'aetherial', 'mild', and 'light', which even vaguely recalls the properties of Being.

der Sprache', 134-143, Fehling 1965, 212-217 on Protagoras, and Cole 1967, ch. 4 'The origins of language', 6o-6g. Spoerri, Fehling, and Cole fail to mention Parmenides. Gambara 1989, 94 n. 22 recognizes that in Parmenides "le terme ónoma de «nom personnel» s'est généralisé en «mot»" but fails to note the importance of Parmenides' view, and only cites fr. B8.39-40. For Orpheus and others as purported name-givers see Pap.Derv. col. xxii.16. Apparently, this only pertains to divine names, i.e. a class of proper names, see the examples cited in the following columns and in cols. xviii and xix, see Burkert 1970, 444447 (where different numbering of columns). Hdt. 2.53.2 regards Homer and Hesiod as

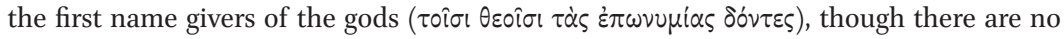
instances in (our text of) Homer of such names. Xavier Gheerbrant reminds me that Pherecydes of Syros frs. $7 \mathrm{~B} 1-2 \mathrm{DK}$ actually gave names to some gods.

37 Identifying the ignorant humans of fr. B6.4-9 with the far from ignorant humans of fr. B8.38-41 and B8.51-59 also facilitates the identification of the account of reality proposed by the latter with the way of not-Being of fr. B2, as argued by Cordero 1979 and 2020, Nehamas 1981, and others; overview in Kraus 2013, 460-461. But the way of not-Being is 'entirely indiscernible', or 'without report' ( $\pi \alpha \nu \alpha \pi \varepsilon \nu \theta \eta$ 's) according to fr. B2.6, so can hardly be identical with the way of the ignorant humans of fr. B6, about which we hear quite a bit, or with that of the other humans of the second part of the epic, about which we hear even more. Cf. also above, n. 28.

38 Arist. Metaph. A 5.986b33-987a2, cf. fr. A24, 'he places the hot on the side of being and the

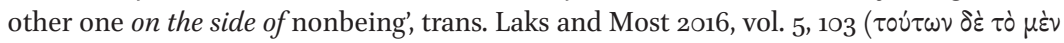
$\tau$ 
On the other hand, as has been seen, both the opposed elements in certain crucial respects resemble Being, ${ }^{39}$ which 'remains the same and in the same

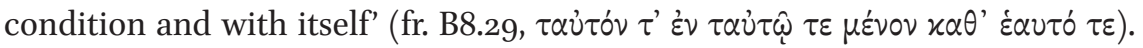
For they are self-identical: Fire is 'in every direction the same with itself' ( $\dot{\varepsilon} \alpha \nu \tau \hat{\omega}$

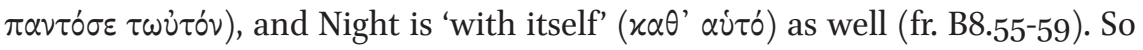
Night is not only associated more Aristotelico with not-Being. Yet neither Shape partakes of 'nothing' (fr. B9.4), just as Being itself (fr. B8.46-47).

The resemblance of the elements and the cosmos with Being has been convincingly argued by Coxon and others and worked out in further detail by Johansen. ${ }^{40}$ Let us follow them most of the way, slightly modifying or adding whatever seems convenient.

At the beginning of the large ontological fragment, the goddess tells us that there are a number of 'signs', $\sigma \eta \mu \alpha \tau(\alpha)$, which are found on the way of Being, namely 'ungenerated, imperishable, entire, unique, unmoved, one, continuous, complete, homogeneous', and others (fr. B8.1-6). ${ }^{41}$ As is proved in what follows these signs represent significant properties uniquely qualifying Being. At the beginning of the cosmology the goddess tells us that the mortals who posited two elemental Shapes distinguished them from each other by assigning 'signs', $\sigma \eta \mu \alpha \tau(\alpha)$ that are 'separate from each other' (fr. B8.55-59), i.e. not only those which, as we have just seen, recall properties that characterize Being, but also marks which do not recall such properties, namely 'aetherial flame-fire, mild, very light' and 'night, dense and heavy' ('occult', as we have seen, recalls not-Being). The third time $\sigma \eta \dot{\mu} \mu \tau \alpha$ are mentioned is in fr. B10.1-2: 'you will know all the signs in the aether', i.e. the individual stars and constellations, ${ }^{42}$ and as we know individual stars and groups of visible

39 Coxon 1986, $223=2009,347$, on fire alone; Johansen 2016, 12-13 on both elements. See also Mansfeld 1964, 131-142, with references to literature in German.

40 Coxon 1986, 223-225, 229-230 = 2009, 348-35o, 356-357, note esp. 1986, $225=2009,351$ on fr. B8.6o ह่oเxó $\tau$ : the cosmology "is as like the one reality as is possible for a dualist order"; Burkert 2008, 14 = 1996, 15: "Licht und Nacht sind beide nur vordergründige Aspekte des einen Seienden"; Sedley 1999, 124: "the detailed descriptions of the cosmos mimic the language of the Way of Truth"; and Johansen 2016, passim. Johansen's careful paper gets short shrift at Corazzon 2019, 125, who only cites its abstract (and moreover exclusively deals with literature in English, which is a serious handicap, while even his overview of literature in English is incomplete). Note that the resemblance of things in the world to Being does not only depend on the way we interpret ह̇oxó $\tau \alpha$ (cf. below, n. 54), but is a matter of similar attributes.

41 For a discussion of the arguments concerned with these properties and their interconnections in fr. B8 see McKirahan 2009.

Not just the 'planets', pace Coxon 1986, $227=2009,352$. 
stars have (been given) significant names. The imposition of meaningful $\sigma \dot{\eta} \mu \alpha \tau \alpha$ on the elements and other cosmic phenomena corresponds with the presence of such $\sigma \eta^{\prime} \mu \alpha \tau \alpha$ on the way of Being. ${ }^{43}$ The noteworthy presence of these $\sigma \dot{\eta} \mu \alpha \tau \alpha$ at the beginning of both the ontology and the cosmology underlines the unity of the poem: the recurrent pattern again. But we need to bear in mind that the signs enumerated and proved in the Aletheia section reveal the nature of Being, and that those of the elements and cosmic phenomena listed and found in the Doxa section are conventional namelabels, although some signs, like self-identity and fullness, are reverberations of descriptive properties of Being and so, as we have seen and shall see, are on a higher doxastic ${ }^{44}$ level.

Together the Shapes constitute a macrocosmic plenum (fr. B9.3, $\pi \hat{\alpha} \nu \pi \lambda \varepsilon_{\varepsilon} \circ \nu$

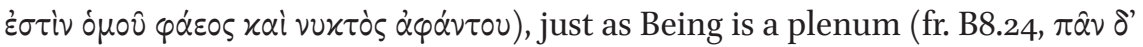

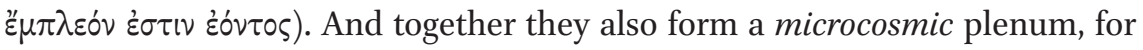

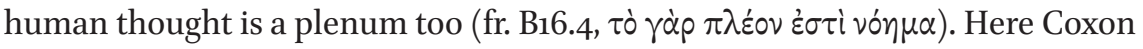
and Johansen, who follow Theophrastus' interpretation that $\tau \dot{0}$... $\pi \lambda \lambda^{\varepsilon} \circ \mathrm{v}$ means 'the predominant', unfortunately neglect to apply their criterium that the 'signs' of the Shapes, both single and combined (as they allow for fr. B9.3), are made to recall those of Being. ${ }^{45}$ Human cognition as described in fr. B16 moreover echoes the sameness of thinking and Being at frs. B3 and B8.34-36. Anankē maintains immobile and unchangeable Being 'within the bonds of the limit' (fr. B.8.31, $\pi \varepsilon i p \alpha \tau \circ \varsigma$ $\dot{\varepsilon} \nu \delta \varepsilon \sigma \mu 0 i \sigma(v)$, while Being is spherical because it possesses this 'outer limit' (fr. B8.42, $\pi \varepsilon i$ pas $\pi \dot{u} \mu \alpha \tau o v)$. The same Anankē dominates the heavens, so that it holds the 'limits of the heavenly bodies' (fr. B10.7, $\pi \varepsilon i p \alpha \tau$ ' ... $\ddot{\alpha} \sigma \tau \omega \omega)$. This recurrent image clearly intimates that the heaven with its system of heavenly bodies is spherical, for which assumption the only reason can be this resemblance to Being. At fr. A37 (Aëtius, Plac. 2.7.1[1] M-R) these 'limits of the heavenly bodies' are called 'bands' ( $\sigma \tau \varepsilon \varphi \alpha \dot{\alpha} \alpha \varsigma)$, so constitute a revised version of Anaximander's speculative system of $x \dot{x} x \lambda$ ol (frs. 12A18, A21, A22 DK). ${ }^{46}$ It is further reported that Parmenides was the first to hold that the earth is spherical (fr. Ar at D.L. 9.21) ${ }^{47}$ This is a revised version of Anaximander's speculative hypothesis that the earth has the shape of a cylinder with precise stereometric dimensions (height 1 to width 3, fr. 12 An DK). Yet the only reason for

\footnotetext{
43 Coxon 1986, $194=$ 2009, 314, cf. 221 = 2009, 346; Johansen 2016, 5-8, 12-18.

44 For doxastic levels see below, text to n. 52 .

45 Thphr. Sens. 1-4, cf. below n. 64 and text thereto. For $\tau \dot{0} . . . \pi \lambda \varepsilon^{\prime} \circ \mathrm{v}$ as 'the full' see Laks 199o; Tor 2017, 165; and Mansfeld 2018, 208-211, with the literature cited ibid., 210 n. 34.

46 I refrain from discussing fr. A37 here and refer to Mansfeld and Runia 2020, 2.852-853; for problems with its interpretation see the discussion of Bollack 2016.

47 Cf. fr. A44 = Thphr. Phys.Op. fr. 17 Diels (= fr. 227 FHS\&G) at D.L. 8.48.
} 
the claim that it has this size is its purported resemblance with the sphericity of Being, which grants perfection on a lower level. That the moon is 'round'

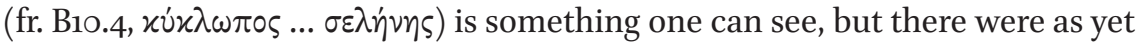
no means or instruments available to provide a measure of confirmation, or proof, of the sphericity of the earth - just as in the case of the heavens and the cosmos, also invested with resemblance with the sphericity of Being and perfection on a lower level. The shape of the earth and the heavens continued to be disputed by the cognoscenti, ${ }^{48}$ though eventually there was a solid majority in favour of sphericity.

Not every 'name' is immediately expressive of this resemblance, for instance the names 'coming to be', 'passing away', 'changing place' and 'altering colour' of fr. B8.4O-41. But the words 'being and not-being' of fr. B8.40 recall the terminology and argument of the first part of this fragment and of frs. $\mathrm{B}_{2}, \mathrm{~B}_{5}$ and $\mathrm{B}_{7}$. The imposition of being as well as, i.e. alongside not-being (which, I repeat, is not the same as confusing them), by ignoring the crucial distinction between Being and not-Being which entails leaving not-Being by the wayside, necessarily allows for 'coming to be' and 'passing away', 'changing place' and 'altering colour'. These names are so to speak encapsulated within being as well as not-

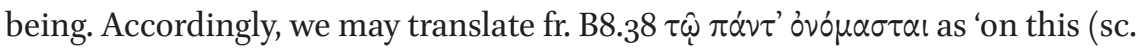
Being) all names are imposed. ${ }^{49}$ The mortals, naming Being, are confident that they are giving it 'true' ( $\dot{\alpha} \lambda \hat{\eta} \theta \hat{\eta})$ names, expressive of its nature and granting its identity, that is, in which they are mistaken. However, the names involved are not 'mere names', but significant and all-important names of processes in a cosmological context. And they recur, in the guise of synonyms, at the end of

48 Other shapes for the heavens (or the world) were posited by 'some' people, namely 'conical' or 'ovoid' (Aët. Plac. 2.2.2-3 M-R), while Epicurus (Ep.Pyth. at D.L. 10.88 and scholion at D.L. $10.74=$ fr. 82 Usener) allowed for shapes such as 'triangular' or 'ovoid' etc. For other shapes of the earth argued not long after Parmenides see Aët. Plac. 3.10.4-5 M-R, on Leucippus ('kettle-drum', 67A26 DK) and Democritus ('disk in breadth, hollow at the cen-

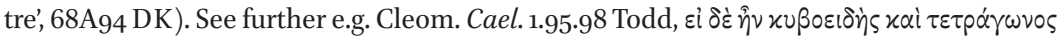

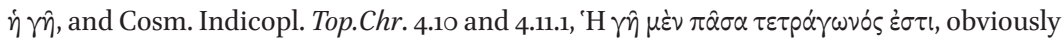
deriving from a confusion with the cubical elementary particles of earth in the Timaeus.

49 First argued by Woodbury 1958; for the reading cf. fr. B9.1, ovó $\mu \alpha \sigma \tau \alpha$. The alternative reading $\tau \hat{\omega} \pi \alpha^{\alpha} \nu \tau^{\prime}$ 'o $v 0 \mu^{\prime}$ ' $\varepsilon \sigma \tau \alpha$, the true one according to Coxon 1986, 211 and others, is translated 'darum wird alles bloßer Name sein' in DK 1.238, 'therefore all those things will be a name' in Coxon 1986, 73, and 'so that a [mere] name will be all the things' in Laks and Most 2016, vol. 5, 49, etc. For $\tau \hat{\omega}$ as demonstrative pronoun and the construction with the dative see

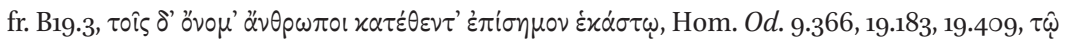

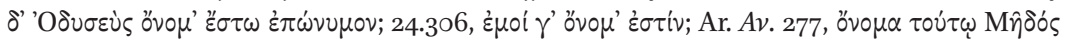

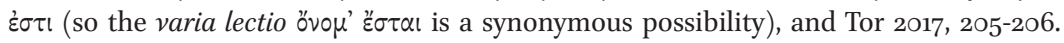
For name-giving cf. Gambara 1989, cited above, n. 36 ad init. That the carefully chosen examples do not relate to unimportant concepts seems decisive. 
the second part; in the closing lines, that is, of the poem - another variety of the recurrent pattern:

Thus, according to Opinion, these things have been born and now they are;

And later, from there, having grown, they will come to their end.

On them humans have imposed a name, as a mark for each one. ${ }^{50}$

Yet, as we have noted, as names given to Being they are mistaken. 'Coming to be' and 'passing away' contradict Being's invulnerability to process as expressed in the primary properties 'ungenerated' and 'indestructible', which these cosmological concepts recall by conflicting with them, as similarly 'changing place' with its immobility. Only 'altering bright colour', thrown in, I suppose, to further exemplify that the processes that are mentioned are cosmological, fails to find such a counterpart among the properties of Being that are described and argued. For Being is not described as colourless.

By imparting some of its constitutive properties to each of the Shapes as well as to certain combinations of (parts of) these Shapes Being in a way functions, or rather is made to function, as what came to be called an $\alpha$ pxy ('principle'). It does so in spite of itself, so to speak, for the presence of these properties is the result of a mistake made by intelligent human agents. A crucial property of Being is moreover withheld from the Shapes, namely indestructibility. In the systems of Anaxagoras and Empedocles and of the early Atomists this property has been imparted to their respective elemental successors of the Shapes, and the uncomfortable idea of an indestructible Being, looming apart from nature in a sort of Beyond, has been abandoned.

The second part of the poem does not present the unsophisticated views of the ignorant multitude, but a sophisticated and original philosophy of nature. That at one time the world will cease to exist, without beginning all over again, an idea not found in Greek myth and very far from general in ancient philosophy, is for the first time explicitly attested in its concluding line (fr. B.19.3,

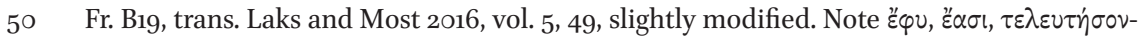

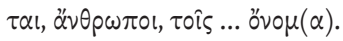


'these things ... will come to their end'). ${ }^{51}$ It will have surprised and possibly even shocked the audience. This thesis is demonstrated indirectly, by implicit reference to the ontology of the first part of the poem, subtly underlining the consistency of its argumentation. Other novel theses are formulated as if they were self-evident, but as we have seen in the previous section crucial analogies with components of the argument of the first part of the poem are also found here.

References to the standard views of the multitude are hidden in a subtext. People will say for instance that, as you can see for yourself, the earth is flat, but there actually is a superior option (fr. A1 at D.L. 9.21, as we have seen), though this is a human belief, too. Many will presumably believe that the moon possesses its own and independent light, but there actually is a superior option, namely that its fiery ingredient only works when it is ignited by the sun, though this is a human belief, too. I suggest that we introduce the notion of a variable 'doxastic level' for human views. The traditional and common opinion which also remains unmentioned, namely that the earth is flat, has a low doxastic level, but the elitist tenet that it is spherical the highest possible doxastic level. ${ }^{52}$ Even so, it cannot reach higher than this highest doxastic level, since epistemic certainty is reserved for the ontological deductions of the first part of the poem. In the same way the view that things in the world are constructed from two opposed elements by a divine Demiurge, introduced in fr. B12, in the manner described in the second part of the poem, is on the highest possible doxastic level, one certainly higher, that is, than what can be conceded to whatever other story or explanation has been transmitted or proposed. Demiurges and elements of various kinds will henceforth populate Greek cosmological theory. A popular embryological belief for which there is archaeological evidence from Paestum, not far from Elea of course, is that males are formed on the right side of the womb..$^{53}$ This piece of folklore is placed on a scientific footing and explained in a rational way, not only by combining the polar opposites left/right with the seed of both parents and its places of provenance and deposition, but primarily by the appeal to the two physical elements. A popular

$5^{1} \quad$ Fr. B19.3, quoted in the text at n. 50 above. For the end of the world in ancient thought see Mansfeld forthcoming.

$5^{2} \quad$ For other shapes of the earth posited by people later than Parmenides see above, n. 48, for the moon and its light below n. 58 and text to this note, n. 6 o.

53 For the association of left with female and right with male as very early Greek beliefs see Lloyd 1972. For the offerings of fictile wombs with pronounced right ovaries in the temple of Hera at Paestum see the paper of P. Ebner (not accessible to me at the moment), cited by Zeller, Mondolfo, and Reale 2011, 278 n.: "si tratta di votivi offerti alla Dea per invocare il concepimento di un maschio" (my italics). 
belief can be revised, and so justified, on a higher doxastic level. The solution provided is therefore the best that can be devised, as is in fact said at fr. B8.6o-61 with regard to the cosmology as a whole: 'I reveal this resembling (and/or: 'likely', ह̇ox'́t $\alpha$ ) cosmic arrangement to you in full, so that no mortal judgement ( $\gamma \vee \omega \dot{u} \mu \eta)$ will outstrip you'.54 So, la meilleure des cosmologies possibles.

'To resemble' something means to share certain features with that something, which as we have seen is indeed the case here. Whether or not one is taken in by a resemblance depends on the position of the beholder. ${ }^{55} \mathrm{~A}$ good resemblance may persuade people to believe that what merely comes near an original is all there is. ${ }^{56}$ This is the mistake made by the humans who gave names to the two Shapes and to things in general, so for them this resemblance is indeed 'deceptive' - one of the nuances the word zoเxó $\tau \alpha$ is capable of conveying, and the meaning of another word at fr. B8.52 ( $\dot{\alpha} \pi \alpha \tau \eta \lambda \hat{\varsigma} \varsigma)$. In this activity they are mistaken. But it is not deceptive for the poet, or his audience. Those who have followed and understood the account-in-two-parts of the goddess know that apart from the resembling world there is also something this world to an important extent resembles. ${ }^{57}$

Parmenides' moon may serve as a symbol here. ${ }^{58}$ There were as yet no means or instruments available to provide a measure of confirmation, or proof,

54 For the semantic richness of the notion of żoxó $\tau \alpha$ and the applicability of its shades of meaning to fr. B8.6o see Bryan 2012, esp. 112-113, who concludes: "[t] his amalgam is best translated into technical English as 'subjective plausibility': what is हixw's seems true, but only to those unprepared to distinguish reality from appearance". This is spot on but appears to disregard the resemblance of the cosmos to the world of Being. Better

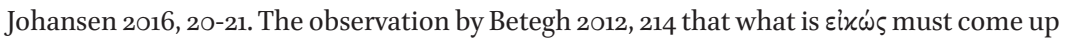
to a positive standard but has its limitations, is most useful. Note that from an etymological point of view the word 'likely' connotes resemblance, just as the French vraisemblable ("composé de vrai et semblable" according to the etymological information available online), the German wahrscheinlich, the Dutch waarschijnlijk, the Italian verosimile, or the Latin veri similis.

55 Well argued by Tor 2017, 199-200.

56 Cf. Bryan 2012 above n. 54, Tor 2017, 168.

57 Cf. again Bryan 2012 cited above n. 54; also, Sassi 2013, 26, though she rejects the meaning 'resembling' for ह̇oเxó $\tau$.

58 Frs. B14 and B15, Aët. 2.30.5 M-R = fr. B21. I accept the suggestion conveyed by the title of Popper's paper cited in the bibliography, but not its implementation. Popper 1992, 14 believes that Parmenides' moon is "a dark sphere of dense matter", but it is a mix of Fire and Night, see below n. 60 and text thereto. He argues that Light is an unwanted elemental Form, that it is Night which should be ranged with Being; he is followed by e.g. Sedley 1999, 124 and Primavesi 2011, 225-227 = 2013, 76-78. But as we have seen in Section 4 above, the two elements are exactly the same in their dependence on Being as self-identical entities, and they have exactly the same function, both individually and together, in the construction and constitution of the cosmos and what is in it; cf. Cosgrove 2011, 35-37. 
of the assumption that the moon in some way or other owes its being capable to shine to the sun. The issue continued to be disputed by the cognoscenti. ${ }^{59}$ According to Parmenides the sun ignites the fiery part of the substance of the moon by projecting its rays upon the moon, thereby permitting it to shine. I assume that for him this dependence amounts to a sort of inner-cosmic resemblance, the moon becoming a sort of quasi-sun. During the night people do not see the sun itself but only its representative, the moon, 'an alien light shining by night, wandering round the earth', 'always looking for the rays of the sun' (frs. B14-15). The moon plays an indispensable role, allowing people to see the sun too, and by proxy, even if they are unaware that this is a decisive component of what they are seeing. That it plays an active role is clear from fr. B10.4, which mentions its 'works', हैpro.

It would seem that Parmenides holds the extramission view of seeing by means of rays sent out from the eyes. Fr. A48 at Aëtius 4.13.6 M-R explicitly attributes the view of Hipparchus, cited at 4.13.4, that 'rays stretching from each of the eyes deliver apprehension of external bodies', to 'Parmenides who shows this through his verses' ( $\delta \dot{\alpha} \tau \omega \hat{\omega} \nu \pi \circ \eta \eta \mu \dot{\alpha} \tau \omega \nu)$. We know that the eye 'directed'

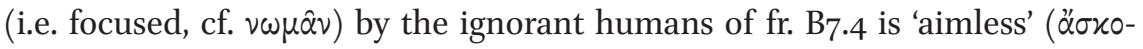
$\pi \circ \varsigma$ ) so does not find its object, and that the moon 'is looking for' ( $\pi \alpha \pi \tau \alpha$ ivov $\sigma \alpha$ $\pi$ זós) the rays of the sun, which it can do only if it possesses some fire of its own that sends out rays, for light rays are fiery. ${ }^{60}$

59 See e.g. Epic. Ep.Pyth. at D.L. 10.94-95; Lucr. 5.715-55; Aët. Plac. 2.28 M-R; Philo Somn. 1.23; Cleom. Cael. 2.4.1-3o Todd, Aug. Enarr. in Ps. 10.3.2-30 Dekkers and Fraipont.

6o So, we should not speak of reflected light, see discussion at Mansfeld and Runia 2020, 2.1071, 2.1097-1098 with proof that Diels was wrong in rejecting Aët. 2.30.5 M-R = spurious fr. B21 DK: the moon appears to be earthy 'because the fiery is mixed with the

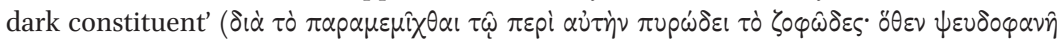
['falsely appearing', $\psi \varepsilon \cup \delta 0 \varphi \alpha \hat{\eta}$ Meineke] $\lambda \dot{\varepsilon} \gamma \varepsilon \sigma \theta \alpha \mathrm{l} \tau \dot{\partial} v \dot{\alpha} \sigma \tau \varepsilon \dot{\varepsilon} \rho \alpha$ ), cf. Aët. 2.20.16 M-R = fr. A43, 'Parmenides (says that) the sun and the moon have been separated off from the circle of the Milky Way, the former from the more rarefied mixture, which is hot, the latter from the denser (mixture), which is cold'. See Mansfeld and Runia 2020, ibid. for references to the literature, e.g. Wöhrle 1993 and esp. Couprie 2018, 195-218; also see the pioneering paper of O'Brien 1968 and Conche 1996, 235-236. I now believe that Meineke's conjecture

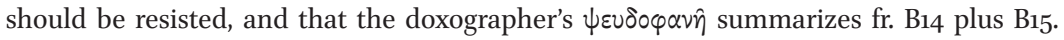

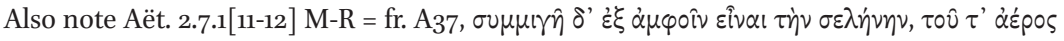

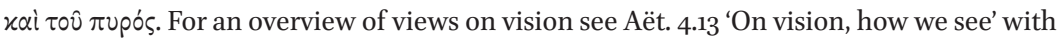
commentary in Mansfeld and Runia 2020, 3.1621-1651, esp. p. 1631 on the sun who 'sees' i.e.

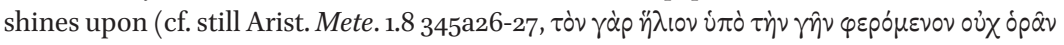

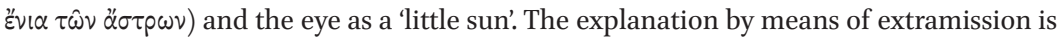
the (often naive) majority view, cf. Cerri 1999a, 276. The verses to which Aët. 4.13.6 M-R = fr. A46 refer appear to be lost, but the verbatim evidence cited in the text is sufficient. 
But due to the exposition of the goddess Parmenides' audience becomes aware of this situation. Once correctly understood, the 'false light' (Aët. 2.30.5 $\mathrm{M}-\mathrm{R}$ ) of the moon is found to be on a doxastic level that is comparable to, though on a lower echelon than that of the elements of fr. B8.51-54; it certainly is more than a symbol of falsity. ${ }^{61}$ We may surmise that the injunction of fr. $\mathrm{B} 4$,

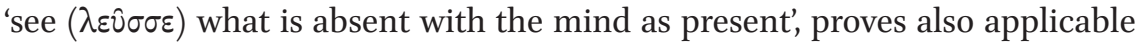
here. ${ }^{62}$ To understand what happens we have, so to speak, to look backwards 'with the mind' from the moon to the sun and forward from the sun to the moon. In the same way, we have to look backwards from the second main part of the poem to the first main part and forward to this second part from the first. The 'signs' that define the Shapes and the cosmos resemble some of the 'signs' of Being. Knowledge of the constitution of Being is required to understand the Shapes and the cosmos, and knowledge of the properties of the Shapes, and of their compounds and the cosmos, to some extent helps understand Being and may eventually serve as a stepping-stone towards this insight. Accordingly, we have to study Parmenides both from right to left and (as in the usual way) from left to right. I suggest that we link the words of the goddess in fr. B5: 'it is all the same for me from where I begin, for there I shall come back again', ${ }^{63}$ with this requirement. We have to be cooperative, and to follow her example.

There is room for levels of doxastic difference also in the account of human cognition in fr. B16. That the 'limbs' are 'much-wandering' ( $\mu \varepsilon \lambda \varepsilon^{\prime} \omega \nu \pi 0 \lambda \nu \pi \lambda \lambda^{\alpha} \gamma \gamma-$ $\tau \omega \nu$, Theophrastus' text) ultimately derives from the general mistake concerned with the elements described at the beginning of the second part of the epic. But this does not exclude a distinction between individuals who make intelligent mistakes, and the majority which find themselves in a condition of utter helplessness. And according to Theophrastus, who with the phrase $\dot{\varepsilon} v$ ois ynoiv refers to a passage the verbatim text of which is lost, a corpse is only aware of cold and silence and suchlike. ${ }^{64}$ This clearly is a very low level of doxastic cognition. The microcosmic plenum is now filled by Night alone but is still a plenum. We are not informed about cognition when this plenum would be filled by Fire alone, when one supposedly would only be aware of heat and sound and suchlike, and one may hesitate to believe that this was considered

61 As is argued by Popper 1992 and Primavesi 2011, see above n. 58 .

62 I note that Laks and Most 2016, vol. 5, 53 place this fragment near the beginning of the second main part of the epic, but it holds equally in respect of both main parts.

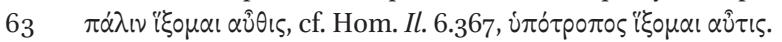

64 Thphr. Sens. 4 (fr. A46 DK). The phrase need not refer to more passages than one, cf. e.g. Pl. R. 392e, Gal. PHP 7.5.48, S.E. M. 7.8, Simp. in Ph. 171.1-2, and expressions such as ह่v oí

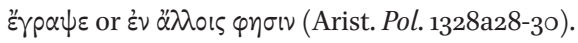


by Parmenides for human beings as long as they were alive, or to be the condition of a disembodied soul. ${ }^{65}$

The extended pattern of presentation is geared to the gradual disclosure of the main issues of the epic, as becomes clear on hearing or reading it for a second or third etc. time. The lines about the names changing place and altering bright colour of fr. B8.38-41, of which as they appear for the first time it is not clear what exactly they refer to, can subsequently be seen as pertaining to the celestial phenomena of the Doxa section. The announcement in fr. B1.28$3^{2}$, the intentional obscurity of which is a normal feature of a proem, ${ }^{66} \mathrm{can}$ be also infused with meaning, for the lines about the Opinions of mortals in which there is no true trust and which are contrasted with the Truth, but which should nevertheless be understood as having a sort of universal validity, can now be interpreted as pertaining to the doxastic maximum presented in the second part of the poem. The explicit contrast between Truth and mortal error, a true leitmotiv, occurs again at the pivotal passage fr. B8.50-53.

We again recognize the presence of organizing devices that help to construct a coherent ensemble. To this end certain crucial notions occur repeatedly and variously, and in several contexts and combinations. Parmenides has brilliantly used the epic technique of 'recurring theses' and 'type-scenes' to give his poem a solid architecture, and so to ground his cosmology in his ontology. ${ }^{67}$

65 See Mansfeld 2018a, 209-210 $=2018 \mathrm{~b}, 182-183$. The passage in Simplicius according to which 'the goddess sends the souls now from the visible to the invisible and then back

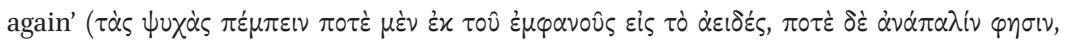
in Phys. 39.19-21 = introd. to fr. $\mathrm{B} 13$ = test. 207 Coxon) remains enigmatic, as we have no further information on the lines Simplicius is briefly paraphrasing here. Tor 2017, 233-250 and 2020 argues that it is about metempsychosis, but the report of Aët. 4.3.4 M-R = fr. A45 that according to Parmenides the soul is 'fire-like' ( $\pi \cup p \omega \dot{\delta} \eta)$ does not entail that it is pure fire, but only that it is a blend of fire and something else-in fact of earth and fire, as Macr. in Somn. 1.14.20 (also at fr. A45) has it, and as indeed Theophrastus tells us, when (Sens. 3) he states that for the living human being cognition is a matter of the blend of the hot and the cold element in its constitution, and though the cognition by means of the hot element is 'better and purer', this (sc. cognitive factor) too needs 'some balance',

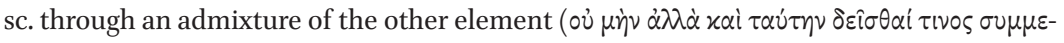
$\tau$ тi $\alpha$ s, A46.9 DK). See Mansfeld 2018a, 210-211 = 2018b, 183-184.

66 See Mansfeld 1995.

67 Cf. Gheerbrant 2018, 73: "Empedocles appropriates the devices with which the archaic epic poets organize their poetic material and adapts them to his specific needs". It would seem that in this novel way of using a traditional technique he is indebted to Parmenides, 
The technique itself is not original, but the contents of these repeated motifs (such as the mention of humans, of name-giving, or of the distinction between Being and not-Being, or of defining properties) are new. Major features of the physical world are coupled in this way with the metaphysics, and the second part of the epic is firmly chained to its first part. In this way conditional acceptability is imparted to the physical doctrines of Doxa part of the poem.

I therefore argue that the World of Opinion, the theme of the second part of the poem, presents us with a necessary intermediate between the two extremes of Parmenides' dualism, namely the unilluminated and helpless condition of the common run of humanity on the one hand, and the World of Truth on the other.

A familiar phenomenon in dualist systems is the presence of intermediate entities that in some way or other partake of both Worlds, bridging the gap between them. ${ }^{68}$ We may for instance think of the soul, or rather the intellect in Plato's philosophy, able to find and retain access to the transcendent Forms even while being in the body, and of the middle part of this tripartite soul, called thymos, that functions as the intermediate between the intellect above and the appetitive part down below. Or of his mathematicals, partaking both of the plurality of things and the unicity, immutability and eternity of the Forms (dixit Aristoteles). Or of his cosmological mediator, the divine Demiurge, capable of infusing things with resemblances of Forms.

Another well-known example is provided by the in-between in Descartes' system. Descartes sharply distinguishes and absolutely separates from each other the res cogitans, or human soul, and the res extensa, or matter (think for example of the fourth Meditation), but of course still has to find a way to allow the soul to influence the body, and conversely. There is a sort of button in the brain, the pineal gland or epiphysis cerebri, where the unextended soul has access to and command over the extended body. This gland transfers sense data to the soul and directs the streams of 'animal spirits' (spiritus animales) that determine the movements of the body. 69

Such bridging constructs, present in various ways in several systems, remind one of Lovejoy's well-known unit-ideas.

Both ignorant humanity in general and its elite and name-giving minority are, as has been said, human, and both are mistaken; this creates a commonality

as he is in other respects. Empedocles is (perhaps self-consciously) explicit about this feature, see fr. ${ }_{11} \mathrm{~B}_{25}$ DK at Schol. in Gorg. $498 \mathrm{e}$ 'for it is a good thing to state twice what has

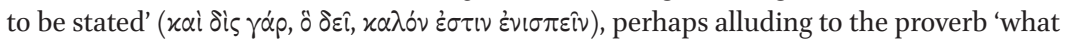

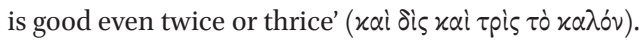

68 See Passmore 1961, ch. 3: 'The two-worlds argument'.

69 See Canguilhem 1977, 27-36. I owe this reference to my colleague and friend Theo Verbeek. 
between the former and the latter. The poet, too, is human (fr. B1.3), but in an exceptional position. The elite minority is far less wrong than the common run of humankind, for the multiple things in their World succeed in mirroring and approximating the properties of true Being, so in this respect their vision does interact with the World of Being in a significant way, and conversely. That this concatenation failed to impress Zeno and Melissus, or to satisfy Anaxagoras and Empedocles, or Leucippus and Democritus, is another matter.

These considerations can be added to other arguments in favour of the seriousness of Parmenides' cosmology that have been propounded..$^{70}$

Another intermediate is found in the proem. The spectacular journey of the kouros, from the dwelling-place of humans to the mythical and far-away house of Night, where the goddess lives who will tell him how the system works, sometimes explained by scholars in terms of shamanism or as an Orphic journey to the nether world, or even accepted as a genuine mystical experience, ${ }^{71}$ makes one think of the role of the human soul in Plato's philosophy.

This intermediary function holds even if, as I have come to believe, the account of this journey is a clever literary construct rather than the record of a genuine experience, or of a case of self-delusion. ${ }^{72}$ Mysticism is a term that is often used inappropriately. Note that Parmenides does not say or hint that his experience is so extraordinary that it cannot, or hardly, be put into words,

70 Summary at Kraus 2013, 496; see also Cerri 2012, discussion at Cosgrove 2016; Tor 2017, 164-165, 206; and Mansfeld 2015, section $3=$ 2018, 191-197.

71 See next $\mathrm{n}$.

72 See also below, n. 87, n. 88, and n. 89 and text thereto. Tarán 1965, 17-31 rewardingly criticizes various interpretations (allegorical, shamanistic, Orphic, mystical) of the meaning of the proem that have been proposed. One can only agree with his conclusion, ibid. 31 . that "the proem is only a literary device", though he fails to realize, or perhaps refuses to consider, the implications of the presence of the Heliades and the chariot as pointers to the Phaethon story. Cassio 1996, 20 argues that the linguistic parallel between Parmenides'

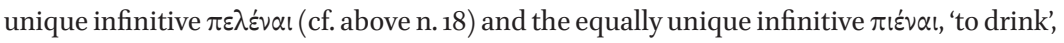
in the Orphic tablet from Hipponion safely dated to ca. 400 BCE (Graf-Johnston 1.12, fr. 474 F [A 62] C.; line 12 Bernabé, line 15 in the reconstructed Orphic urtext of Janko 2016b, 23, cf. ibid. 119 and 125-126 on Parmenides' usage) attests a 'solidarietà linguistica' between Parmenides and the Ionic model of the latter, which significantly enhances the value of other parallels between the two types of text. In my view the latter conclusion goes a bit far. On Greek shamanism as a chimera see ch. 3 of Bremmer 2002, 27-40. For a strong argument in favour of a rationalist interpretation see Granger 2008, for one in favour of a more religiously coloured one Trépanier 2010, 289-298. Gemelli Marciano 2013, closely following Kingsley 1999 and 2003 on whom see above n. 3, favours a genuine mystical experience. For Laks 2013 see below, n. 89 and text thereto. Tor 2017, 250-277 argues on insufficient grounds (see above, n. 65) that the proem describes the journey of a disincarnate soul. Betegh 2006, 29-30, discussing what he calls "the journey model", does not go beyond the post mortem journey of souls (note that he does not mention Parmenides). 
which is what one would expect from a mystic. Quite the contrary, for the elaborate account of his purported experience is full of details. He has worked hard to make us believe that this journey really happened, and that he really heard a goddess, for (like Hesiod) he needs divine backing for his stunning doctrine.

The poem is a first-person narrative. Lines 1 and $23-26$ of the proem tell us that what takes place here is a fragment of autobiography: 'the horses carry $m e$ as far as my thumos allows' (fr. B1.1), 'the goddess received me' (B1.22), 'addressed $m e^{\prime}$ (B.1.23), and twice she says 'you' (B1.25-26). Thus, the record has been written by the person who narrates the exceptional journey. ${ }^{73}$ This constitutes the first authenticating device, ${ }^{74}$ and in what follows it is echoed each time the goddess uses a verb form in the second person singular. In the proem it is accompanied by a rich combination of further such devices, both visual and auditive, namely the dramatic description of the loud shriek of the flaming axle of the chariot caused by the rotation of a wheel on either side, of the construction of the gates of the ways of Day and Night (reminiscent of passages in Homer as well as Hesiod) ${ }^{75}$ with lintel and threshold of stone and with mighty doors turning in their sockets in the bronze-fitted posts, fixed to them with pegs and nails. ${ }^{76}$ The poet is then carried straight along the driveway to be received by a goddess, who welcomes him and takes his hand. ${ }^{77}$ This poem is not concerned with a bygone age, as the epics belonging to the Trojan or Theban cycle, but with a recent event that is drawn in a realistic way.

We should also note that the poet does not ask the Muses, or a Muse, to inspire or to tell him, as occurs in the Iliad and Odyssey and also in Hesiod and Solon and in Empedocles, ${ }^{78}$ or is visited and addressed by them as happens to Hesiod at the beginning of the Theogony. ${ }^{79}$ In Parmenides' poem a nameless poet-narrator is traveling of his own free will (fr. B1.1, cited below) to a nameless goddess $(\theta \varepsilon \dot{\alpha})$ in her own, far away abode, ${ }^{80}$ who welcomes and addresses him only after he has safely arrived. He has clearly been expected. Throughout

73 An epic parallel is provided by the Arimaspea attributed to Aristeas of Proconnesus, as it seems to be dated to the second half of the sixth century, which purports to be an account of a journey of the narrator far north of the Black Sea; see Ivanchik 1993 and Bremmer 2002, 33, 38 .

74 As already noted by Diels 1897,14 . See Bremmer 2018, 105 with $\mathrm{n} .68$, also for parallels.

75 Hom. Il. 5·748-752, Od. 10.86, Hes. Th. 748-754, 811.

76 For such normal and everyday details in a context that is far from ordinary see Mansfeld 2011, 294. They are often found in fairy tales.

77 I here cannibalize Coxon's translation.

78 E.g. Il. 1.1 where she is addressed as $\theta \varepsilon \dot{\alpha}, 2.484,491,11.218,16.112, O d .1 .1$ (taken up with $\theta \varepsilon \dot{\alpha}$ in 1.10), Hes. Th. 114-115, Op. 1, Sol. fr. 13.1-2 West, Emp. frs. 31B3.3 and B131 DK.

79 Hes. Th. 22-34, where the poet is (exceptionally) addressed by his name.

$80 \quad$ Cf. Primavesi 2011 cited below, n. 85 . 
the extant remains she remains nameless. Unlike the poets just mentioned our author does not speak to her, but just listens to what she wishes to tell him.

Quite remarkably, in fr. B1.25 the goddess quotes and adapts most of the first line of the proem, i.e. the beginning of the poet's authenticated description of his journey, as if she had listened to a performance or been reading the text. For his part, in fr. B1.1 the traveller-narrator, who is on his way in a fictitious

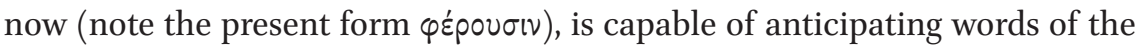
goddess he has still to hear:

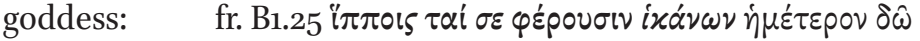

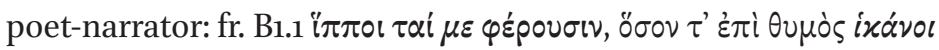

It would seem that this is not just another ring-compositional effect, or a matter of epic repetitive style. ${ }^{81}$ The proem has been composed in a very careful way. My impression, therefore, rather is that this symmetry reveals that the contents of revelation of the goddess are in reality the work of the author, which in my view they are.

This spectacular journey and encounter apparently take place in the world of Doxa. In their more everyday appearance, Day, light and fire, and Night are very much present in the proem, and prelude upon what is revealed about their truer nature in the second part of the poem. ${ }^{82}$ This constitutes a further authenticating device: we should indeed believe that the journey has really happened in the Doxa world of gods and men, a world that should be taken seriously. The discourse of the goddess, codified in an epic composed by a human being, takes place here. But its contents, the doctrine of Being and the cosmology, constitute meta-information about this world. Disertis verbis, each of these disquisitions only possesses verbal existence, the first as an 'authorita-

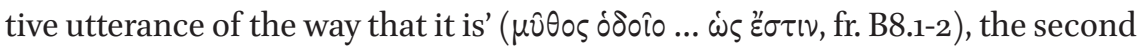

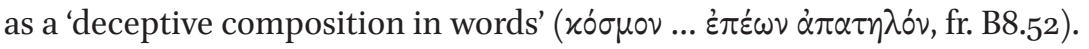

Parmenides presents his doctrine in a dramatic way, using spectacular scaffolding and personification ${ }^{83}$ throughout, in order to be understood by his audience, and to impress. ${ }^{84}$ Where we perhaps would speak of a fabulous discovery, an overwhelming piece of luck, he constructs an astounding poetical

81 As is the case e.g. at $O d$. 4.154, where the speech of the character Menelaus ends with a line that as 4.115 is part of the narration by the narrator.

82 Cf. Kranz 1967, 133 (= 1916, 1165).

83 Cf. above, n. 23 and text thereto.

84 As Most 1999, 346-348 points out, this purpose explains the choice of poetry as the vehicle of communication by Xenophanes, Parmenides and Empedocles, the latter two claiming inspiration by a divinity (in different ways, see above, text to n. 78 and n. 79 ). 
journey to a place far from the path of men, where he meets a goddess who reveals to him how the system works. ${ }^{85}$

In the first part of the poem we encounter Amēchaniē, a divine personality which renders people helpless as regards cognition. In the proem we also meet

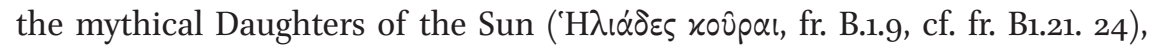
the sisters of Phaethon, whose journey in the sun's chariot famously had a different ending, and who in the various versions of the myth play a part that is very different from the one they play here. I believe that it is quite likely

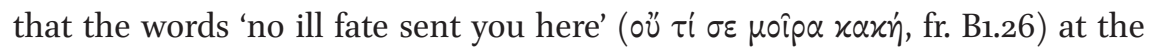
beginning of the goddess' little speech of welcome ${ }^{86}$ hint at the contrast with Phaethon's undertaking. This hint is strengthened by the goddess' insistence that, on the contrary, it was Themis and Dikē (a unique pair) who did so. Most remarkably, Themis, as a rule standing for the traditional order of things, with the assistance of Dikē here favours an extraordinary event. A chariot, and a charioteer with well-behaved horses, who cooperates with the Heliades who have come to meet him. ${ }^{87}$ Heliades as guides who diplomatically intercede with the custodian of the gates and make sure that a journey far from the paths of men to the ends of the earth goes well, and ends well—for people living in the sphere of Greek myth, the association with Phaethon's hubristic and fatal journey with wild horses and without such guidance, must have been virtually unavoidable. ${ }^{88}$ That Phaethon steered the chariot himself and the poet

85 For the itinerary see Mansfeld 1964, 239; Burkert 2008, 6-13 = 1969, 5-15; Primavesi 2o11, $194-211=2013,5^{\circ-70}$, and ibid. $5^{1}$ on Parmenides leaving the earth before meeting with the Heliades under his own poetic steam, so to speak (cf. above, text to n. 80). The hesitations of Granger 2008, Laks 2013 and Tor 2017, 347-359 are unnecessary.

86 As Gerard Boter points out to me, this may well be a litotes: 'a most auspicious Fate sent you here'; see already Floyd 1992, 256.

87 Janko 2016a, 16-17 has read $\theta$ ] unòs ix $\alpha$ [ $[$ or in the Derveni papyrus (fr. G 16.3), the concluding words of Parm. fr. B1.1, so this line and perhaps a bit more seem to have been quoted there; see also Kotwick 2017, text §2[39] and commentary 107-108. Janko, ibid. 17, argues that "at the opening of his poem he [sc. Parmenides] is a natural scientist ( $\varphi$ vowós) who is speaking like an allegorist or mythographer". That by quoting the line in the first section of his treatise (dealing with the rites) the author of the Papyrus text perhaps links Parmenides' proem with the mysteries does not entail that he is right, for his exegesis of words and lines is often arbitrary. The Heliades (see next $n$.) do not belong with the divine population of the mysteries.

88 The story of Phaethon and the Heliades as counterpart to the setting of Parmenides' journey is discussed by Kranz 1967, 129 (= 1916, 1159); Bowra 1937, 103-104 (= 1953, 45-46); and Burkert 2008, 6 = 1969, 5. Kranz calls Parmenides "ein glücklicherer Phaethon". The association did not escape Coxon 1986, 16o = 2009, 274, who, stating that Parmenides "ignores the story of their [sc. the Heliades'] transformation [sc. into poplars] ... and therewith [sic!] the whole story of Phaethon", still prefers to annul the connection. I am in favour of an intertextual allusion even without text (for this notion cf. Burgess 2006), emphasizing 
does not is an essential difference. We should think of ready knowledge, of a shared mythic canon, a culture-wide web or network of interlinked stories and images, allusions to which are immediately, or gradually, or eventually understood by members of an audience that has been nurtured on them and remembers them. André Laks has usefully described such allusions as 'references': the poet uses a variety of traditional images, such as the poet's chariot, or the gates at the far end of the world, in an original way. ${ }^{89}$

In the course of the description of Being we meet with divine personalities such as Dikē (fr. B8.14, previously encountered in the proem, fr. B1.14-16 and 32), Anankē (fr. B8.30), and Moira (fr. B8.37, also previously encountered in the proem, fr. B1.26), personifying what we would call logical proof, the quod erat demonstrandum. While presumably we would call the physics of the second part a hypothesis, ${ }^{90}$ once upon a time there were according to Parmenides human agents, constituting an elite, who set up this edifice, and their view, though the best possible, remains inferior to absolute Truth, in the same manner as for us today doxastic logic comes second after epistemic logic. There is

contrast. Phaethon is variously said to have mounted the chariot without his father's knowledge (Hyg. Fab. 152a), or in spite of his warning (Ov. Met. 2); Pl. Ti. 22c speaks of his inability to stick to his father's route and its disastrous consequences. There are various versions of the role played by the Heliades too. According to Hyginus loc. cit. they were changed into poplars because they had harnessed the horses of the chariot without their father's permission, according to other versions merely because they had mourned their brother's death. Myths are living tales, amenable to change and occurring in various

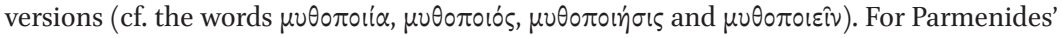
creativity in constructing his mythical opening scene see Kranz 1972, 131 (= 1916, 1163), "daß dem Ganzen eher eine Konstruktion als ein dichterisches Erlebnis zugrunde liegt", and Bowra 1937, esp. p. 99 (=1953, 40), "Parmenides' picture is consistent and sustained; it creates what is almost a new myth". Thus, an almost perfect instance of bricolage, anticipating Levy-Strauss' La pensée sauvage of 1962. See further the paper of Meijer 1984 (trans. of the Dutch title: 'Parmenides' fr. 1 or "how do I make a myth"), who however fails to refer to Phaethon. For Tarán 1965 on this point see above n. 72, for Janko n. 87. For the useful advice of Julius Pollux see above, n. 14. Calame 2013, 75, commenting on the proem, aptly characterizes it as a "scène moins d'inspiration que de constitution du poète en auteur de savoir". The association with Phaethon does not preclude a simultaneous one with the well-known image of the chariot of song mentioned by e.g. Bacch. Epin. 5.176-179 and Pi. O. 6.22-24; see Kranz 1972, 131-132 (= 1916, 1163-1164), and Bowra 1937, 101-102 (= 1953, 41-43), who rightly include this motif as part of the composite picture. On the chariot of song see also Calame 2013, 71-72, 77. I note in passing that Kranz and Bowra are not cited in the rich bibliography of Gemelli Marciano 2013.

89 Laks $2013,85-87$. He need not have compromised by allowing for a mystical side to the description of the journey. For the gates see above, n. 76 and text thereto. Popper 1992, 12 not inappropriately speaks of "the way of human conjectures". 
after all a major difference between the pure realms of logic and mathematics on the one hand, and the world we live in and try to understand on the other.

The only explanation for the presence of elemental properties on a macroand micro-cosmic level, some of which resemble and mirror certain properties of Being, is the claim that they were imposed by these humans. How they arrived at their view of the nature and properties of the elements remains unclear, but it is clear that they were unable to go beyond reverberations of Being shared by two entities both individually and in combination and failed to reach Being itself. This is their mistake.

The suggestion that they came to recognize Fire and Night on the basis of the presence of these ingredients in their own constitution ${ }^{91}$ fails to account for the primary properties of the individual elements and their combination, namely self-identity and fullness. Who these exceptional agents were, we are not told either. I suggest that we call them homines ex machina, for their presence and novel role have been stage-managed in the same way as the presence and role of the goddess.

We may surmise that Parmenides did not foresee this solution would become a problem. Neither, of course, could he expect that his work would become an inspiration for Greek philosophers from the next generation of Presocratics till the end of Antiquity.

Another example that comes to mind is the ground-breaking cosmological system of Anaximander. No one will of course contend that it remained valid per se, but no one, I presume, will deny that it was its empirical-mathematical methodology combined with its eminent and proven revisability that made it the progenitor of a succession of impressive cosmological systems. Works of genius that mark a novel development, like Anaximander's cosmological system or Parmenides' epochal metaphysics and his seminal physics (one of the early updates of Anaximander's system), should not only be treasured in themselves, but perhaps be appreciated even more for inspiring the science and philosophy that followed on after them, for they proved to be wonderfully capable of being revised and improved.

That it is possible to dispense with Parmenides' panoply, with (in Bowra's words $)^{92}$ the "almost new myth" of the proem, and the rest of his recondite trappings, though at a cost, is demonstrated for the Parmenidean metaphysics by Melissus' elaborate revised version of the ontology in archaic prose. ${ }^{93}$

\footnotetext{
91 Tor 2017, 193, 196.

92 Above, n. 88.

93 Mansfeld 2016.
} 
Melissus also used anaphora and reiteration to promote his message in a more intermittent way. ${ }^{94}$

In conclusion, I believe that it is worth the effort to consider the vexing and vexed issues that have bedevilled the interpretation of the epic of Parmenides from the contextual and macro-structural point of view that has been proposed in the present paper. A perhaps unexpected parallel for the Parmenidean conundrum (a partial one, as such parallels usually are) is provided by Schopenhauer. In the introduction to his very readable Aphorismen zur Lebensweisheit (The Wisdom of Life) he states that this eudemonistic counseling, "teaching us how to lead a happy existence" ("Anweisung zu einem glücklichen Daseyn"), conflicts with his "philosophical system" ("meine Philosophie"), which denies that this is possible: "I have shown, in the second volume of my chief work ("Hauptwerk", ch. 49), ${ }^{95}$ that this hypothesis is based upon an innate mistake ("angeborenen Irrthum") ... Accordingly, in elaborating the scheme of a happy existence, I have had to make a complete surrender of the higher metaphysical and ethical standpoint to which my own theories lead; and everything I shall say here will to some extent rest upon a compromise; in so far, that is, as I take the common standpoint of every day, and embrace the error ("Irrthum") which is at the bottom of it. My remarks, therefore, will possess only a qualified value ("demnach kann auch ihr Werth nur ein bedingter seyn")." ${ }^{96}$

Unlike the dualism of Parmenides (or Plato, or Descartes), however, that of Schopenhauer is not attenuated by an intermediate entity between the severe theory of his Hauptwerk and the relaxed doctrine of the Aphorismen.

\section{Acknowledgments}

Thanks are due to Mauro Bonazzi for encouragement; to Gerard Boter for useful suggestions and pertinent criticisms which sharpened my thinking; to Jan Bremmer for useful comments, for suggesting that I consider Pap. Derveni col. xx and for sending a copy of his paper on Kingsley; to Richard McKirahan

\footnotetext{
94 On demonstration by anticipation and reiterated explicitation in Melissus see Mansfeld 2016, 78 .

95 I.e. Die Welt als Wille und Vorstellung (The World as Will and Representation).

96 Quoted from the original German in the Schopenhauer edition of Julius Frauenstädt 1877, 331-332 and the online translation of T.B. Saunders of 189o, slightly modified; italics added. In the "Fragmente zur Geschichte der Philosophie. §2 Vorsokratische Philosophie" (Schopenhauer 1877, 36-37) he cites the Eleatics as the first to distinguish between "phaenomena" and "noumena", cf. Ingenkamp 1991, 52, and for Schopenhauer's eudemonism Ingenkamp 2006.
} 
for sending a copy of his chapter on fr. B8; to Xavier Gheerbrant for a close reading of the text, for weeding out typos, for various useful suggestions and for sending a copy of his paper on Empedocles; to André Laks for his appreciation, for his references to works by Jean Bollack, and for sending a copy of his Phenomenon and Reference paper; and as always to David Runia for his repeated scrutiny of the argument and the removal of infelicities. Thanks are also due to the referee of Mnemosyne for weeding out typos and her/his careful and critical scrutiny of the text. Remaining errors are of course mine.

\section{Bibliography ${ }^{97}$}

Anderson, Ø., and Haug D.T.T., eds. (2006). Relative Chronology in Early Epic Poetry. Cambridge.

Atwood Wilkinson, L. (2009). Parmenides and to eon. Reconsidering Muthos and Logos. London.

Auroux, S., ed. (1969). Histoire des idées linguistiques, Vol. 1: La naissance des métalangages en Orient et Occident. Liège.

Bernabé, A. (2005). Poetae epici graeci. Testimonia et fragmenta, Pars 2: Orphicorum et Orphicis similium testimonia et fragmenta, Fasc. 2. Munich.

Betegh, G. (2006). Eschatology and Cosmology. Models and Problems. In: M.M. Sassi, ed., The Construction of Philosophical Discourse in the Age of the Presocratics, Pisa, pp. 27-50.

Betegh, G. (2012). What Makes a Myth sixw's? Remarks Inspired by Myles Burnyeat's

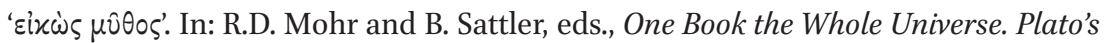
Timaeus Today, Las Vegas, pp. 213-224.

Biggs, T., and Blum, J., eds. (2019). The Epic Journey in Greek and Roman Literature. Cambridge.

Bollack, J. (2006a). Parménide, un auteur. RPhA 234, pp. 45-49.

Bollack, J. (2006b). Parménide, De l'étant au monde. Lagrasse.

Bollack, J. (2016). The Parmenidean Cosmology of Parmenides. In: C. Koenig, L. Muellner, G. Nagy, and S. Pollock, eds., The Art of Reading. From Homer to Paul Celan, Washington DC, ch. 15 [translation of: La cosmologie parménidéenne en Parménide. In: R. Brague and J.F. Courtine, (1990). Herméneutique et ontologie, Paris, pp. 19-53].

Bowra, C.M. (1937). The Proem of Parmenides. CPh 32, pp. 97-112. [reprinted in: C.M. Bowra, ed. (1953). Problems in Greek Poetry, Cambridge, pp. 38-53].

97 Because public libraries are closed or of difficult access during the covid-19 crisis I have not been able to carry out certain checks. Not everything is accessible online. 
Bremmer, J.N. (2002). The Rise and Fall of the Afterlife. London.

Bremmer, J.N. (2018). Method and Madness in the Study of Greek Shamanism. The Case of Peter Kingsley. ASDIWAL. Revue genevoise d'anthropologie et d'histoire des religions 13, pp. 93-109.

Bryan, J. (2012). Likeness and Likelihood in the Presocratics and Plato. Cambridge.

Buglass, A., Fanti, G., and Galzerano, M. (2019). Didactic and Epic Origins, Continuity, and Interactions. In: C. Reitz and S. Finkmann, eds., Structures of Epic Poetry, Vol. 1: Foundations, Berlin, pp. 213-274.

Burgess, J.W. (2006). Intertextuality Without Text in Early Greek Epic. In: Anderson and Haug, eds., pp. 168-183.

Burkert, W. (1970). La genèse des choses et des mots. Le papyrus de Derveni entre Anaxagore et Cratyle. EPh 25, pp. 443-455.

Burkert, W. (2005). Hesiod in Context. Abstraction and Divinities in an Aegaean-Eastern Koine. In: E. Stafford and J. Herrin, eds., Personification in the Greek World. From Antiquity to Byzantium, Ashgate, pp. 3-20 [also in: M.L. Gemelli Marciano, F. Egli, L. Hartmann, and A. Schatzmann, eds. (2003). Kleine Schriften, Vol. 2: Orientalia, Göttingen, pp. 172-191].

Burkert, W. (2008). Das Proömium des Parmenides und die Katabasis des Pythagoras. In:T.A. Szlezák and K.H. Stanzel, eds., Kleine Schriften, Vol. 7:Philosophica, Göttingen, pp. 1-27 [1st ed. in: Phronesis 14 (1969), pp. 12-30; translated as: Parmenides' Proem and Pythagoras' Descent, in: V. Adluri, ed., Philosophy and Salvation in Greek Religion, Berlin 2013, pp. 85-116].

Burkert, W. (2011). Griechische Religion der archaischen und klassischen Epoche. 2nd ed. Stuttgart. [1st edition 1977, trans. of 1st ed. Greek Religion, Archaic and Classical. Oxford 1985].

Calame, C. (2013). Procédures hymniques dans les vers des sages cosmologues. Pragmatique de la poésie didactique (d'Hésiode et Théognis à Empédocle et Parménide). In: R. Bouchon, P. Brillet-Dubois, and N. le Meur-Weissman, eds., Hymnes de la Grèce antique. Approches littéraires et historiques, Lyon, pp. 59-77.

Canguilhem, G. (1977). La formation du concept de réflexe au XVII et XVIII e siècles. 2nd ed. Paris.

Cassio, A.C. (1996). Da Elea a Hipponion e Leontinoi. Lingua di Parmenide e testi epigrafici. ZPE 113, pp. 14-20.

Cerri, G. (1999a). Parmenide, Poema sulla natura. Milan.

Cerri, G. (1999b). La poesia di Parmenide. QUCC 63, pp. 7-27.

Cerri, G. (2012). The Astronomical Section in Parmenides' Poem. In: Cordero, ed., pp. 8o-94.

Cole, T. (1967). Democritus and the Sources of Greek Anthropology. Middletown CO [rev. repr. Atlanta 1990]. 
Conche, M. (1996). Parménide, Le poème. Fragments. Paris. [repr. 20o9].

Corazzon, P. Parmenides. An Annotated Bibliography of Studies in English. Online: https://www.ontology.co/biblio-pdf/parmenides-biblio-english-pdf.htm. (last update April 16, 2019).

Cordero, N.-L. (1979). Les deux chemins de Parmenide. Phronesis 24, pp. 1-32.

Cordero, N.-L. (1984). Les deux chemins de Parmenide. Édition critique, traduction, études et bibliographie. Paris. [2nd ed. 1997].

Cordero, N.-L. (2010). The 'Doxa of Parmenides' Dismantled. AncPhil 3o, pp. 231-246.

Cordero, N.L. (2016). Concerning a Suggested New Arrangement of Parmenides' Fragments, online.

Cordero, N.L. (2019). Les 'opinions des mortels', théorie authentique ou collage de Parménide? online.

Cordero, N.-L. (2020). Gianfranceso d'Asola, el 'creador' de la tercera vía parmenídea. Hypnos 40, pp. 185-195.

Cordero, N.-L. ed. (2012). Parmenides, 'Venerable and Awesome' (Plato, Theaetetus 183e). Las Vegas.

Cosgrove, M.R. (2011). The Unknown ‘Knowing man'. Parmenides B1.3. CQ 61, pp. 28-47.

Cosgrove, M.R. (2014). What Are 'True' doxai Worth to Parmenides? Essaying a Fresh Look at His Cosmology. OSAP 46, pp. 1-31.

Couprie, D.L. (2018). When the Earth was Flat. Studies in Ancient Greek and Chinese Cosmology. Cham, $\mathrm{CH}$.

Coxon, A.H. ed. (1986). The Fragments of Parmenides. A Critical Text with Introduction and Translation, the Ancient Testimonia and a Commentary. Assen. [rev. and expand. ed. w. new trans. by R. McKirahan, new pref. by M. Schofield. Las Vegas 20o9].

Curd, P., and Graham, D.W. eds. (2009). The Oxford Handbook of Presocratic Philosophy. Oxford.

Desbordes, F. (1989). Les idées sur le langage avant la constitution des disciplines spécifiques. In: Auroux, ed., pp. 149-161.

Di Benedetto, V. (1994). Nel laboratorio di Omero. Turin.

Diels, H. (1897). Parmenides, Lehrgedicht, mit einem Anhang über griechische Türen und Schlösser. Berlin. [repr. w. new pref. by W. Burkert, new bibliogr. by D. De Cecco. Sankt Augustin 2003].

Diels, H., and Kranz, W., eds. (1934-1937). Die Fragmente der Vorsokratiker. (3 vols). $5^{\text {th }}$ ed. Berlin. [rev. ed. 1951-1952, and later repr., abbrev. DK].

Ebert, T. (2004). Wo beginnt der Weg der Doxa? Eine Textumstellung im Fragment 8 des Parmenides. In: T. Ebert, Gesammelte Aufsätze, Vol. 2., Paderborn, pp. 9-27. [1st ed. Phronesis 34, 1989, pp. 121-138].

Fehling, D. (1965). Zwei Untersuchungen zur griechischen Sprachphilosophie. I:

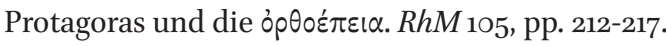


Finkelberg, M. (1998). The Birth of Literary Fiction in Ancient Greece. Oxford. Floyd, E.D. (1992). Why Parmenides Wrote in Verse. AncPhil 12, pp. 251-265.

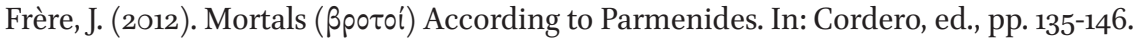
Galgano, N.S. (2016). Amēkhanié in Parmenides DK 28 B 6.5.JAncPhilos (Sao Paolo) 10, pp. 1-12.

Gambara, D. (1989). L'origine des noms et du langage dans la Grèce ancienne. In: Auroux, ed., pp. 79-97.

Gemelli Marciano, M.L. (2013). Parmenide. Suoni, immagini, esperienza. Con alcune considerazioni 'inattuali' su Zenone. In: L. Rossetti and M. Pulpito, eds., Parmenide. Suoni, immagini, esperienza, Sankt Augustin, pp. 43-126.

Gheerbrant, X. (2018). Ritornell and Episodic Composition in Empedocles. YAGE 2, pp. 40-77.

Gianvittorio, L. (2013). Sprechen und Verstehen bei Heraklit und Parmenides. Mnemosyne 66, pp.1-29.

Graf, F., and Johnston, S.-I. (2007). Ritual Texts for the Afterlife. Orpheus and the Bacchic Gold Tablets. London. [2nd ed. 2013].

Graham, D.W. (2019). Heraclitus. The Stanford Encyclopedia of Philosophy (Fall 2019 Edition), https://plato.stanford.edu/archives/fall2019/entries/heraclitus.

Granger, H. (2008). The Proem of Parmenides' Poem. AncPhil 28, pp. 1-20.

Heiden, B. (2007). The Muses' Uncanny Lies. Hesiod, Theogony 27 and its Translators. AJPh 128, pp. 153-157.

Hershbell, J.P. (1968). Empedocles' Oral Style. CJ 63, pp. 351-357.

Hülsz, E., and Berruecos, B. (2018). Parménides B1.3. Una nueva enmienda. In: Pulpito and Spangenberg, eds., pp. 31-6o.

Ingenkamp, H.G. (1991). Der Platonismus in Schopenhauers Erkenntnislehre und Metaphysik. Schopenhauer-Jahrbuch 72, pp. 45-66.

Ingenkamp, H.G. (2006). Schopenhauer als Eudaimonologe. Schopenhauer-Jahrbuch 87, pp. 77-9o.

Ivanchik, A. (1993). La datation du poème l'Arismaspée d'Aristéas de Proconnèse. AC 62, pp. 35-67.

Jackson Rova, P. (2020). The Secret of the Untrembling Heart. A Cryptological Reading of Parmenides' Proem (EGP D4.29/DK B1.119). Mnemosyne 73, pp. 1-20.

Janko, R. (2016a). Parmenides in the Derveni papyrus. New Images for a New Edition. ZPE 200, pp. 3-23.

Janko, R. (2016b). Going beyond Multitexts. The Archetype of the Orphic Gold Leaves. CQ 66, pp. 100-127.

Johansen, T.K. (2016). Parmenides' Likely Story. OSAP 6o, pp. 1-29. Jourdan, F. (2003). Le papyrus de Derveni, traduit et présenté. Paris.

Jourdan, F. (2015). Plutarque développe-t-il réellement une pensée dualiste? In: Jourdan and Vasiliu, eds., pp. 185-224. 
Jourdan, F., and Vasiliu, A., eds. (2015). Dualismes. Doctrines religieuses et traditions phi-

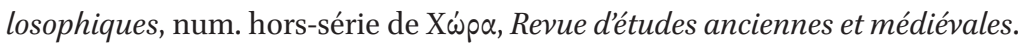

Journée, G. (2015). Dualités présocratiques. In: Jourdan and Vasiliu, eds., pp. 113-140.

Kingsley, P. (1999). In the Dark Places of Wisdom. Inverness, CA. [repr. London 2001].

Kingsley, P. (2003). Reality. Inverness, CA.

Kołakowska, K. (2017). Empedocles of Akragas. Politician and Performer. In: H.L. Reid, D. Tanasi, and S. Kimbell, eds., Politics and Performance in Western Greece, Sioux City, IA, pp. 205-215.

Kotwick, M.E. (2017). Der Derveni Papyrus. Griechisch-Deutsch. Berlin.

Kranz, W. (1967). Über Aufbau und Bedeutung des parmenideischen Gedichtes. In: E. Vogt., ed., Studien zur antiken Literatur und ihrem Fortwirken. Kleine Schriften, Heidelberg, pp. 128-143. [1st ed. SB.Preuss.Ak. 1916, pp. 1158-1176].

Kraus, M. (2013). §12; Parmenides. In: H. Flashar, D. Bremer, and G. Rechenauer, eds., Grundriss der Geschichte der Philosophie. Die Philosophie der Antike, Bd. 1: Frühgriechische Philosophie. Vol. 2, pp. 441-530.

Kraus, M. (2018). William of Moerbeke's Translation of Simplicius' On de caelo and the Constitution of the Text of Parmenides. In: Pulpito and Spangenberg, eds., pp. 213-230.

Kurfess, C. (2012). Restoring Parmenides' Poem. Dissertation, University of Pittsburgh.

Kurfess, C. (2014). Verity's Intrepid Heart. The Variants in Parmenides, DK B1.29 (and 8.4). Apeiron 47, pp. 81-93.

Kurke, L.V. (2007). Archaic Greek Poetry. In: Shapiro, ed., pp. 140-169.

Laks, A. (1990). The More and the Full. On the Reconstruction of Parmenides' Theory of Sensation in Theophrastus, De sensibus, 3-4. OSAP 8, pp. 1-18. [shorter version in Laks, A., Histoire, doxographie, vérité. Études sur Aristote, Théophraste et la philosophie présocratique. Louvain-la-Neuve 2007, pp. 179-192].

Laks, A. (2013). Phenomenon and Reference. Revisiting Parmenides, Empedocles and the Problem of Rationalization. In: S.C. Humpreys and R.G. Wagner, eds., Modernity's Classics, Heidelberg, pp. 165-186. [rev. trans. of Phénomènes et références. Éléments pour une réflexion sur la rationalisation de l'irrationnel. Methodos 3, 2003, https:// journals.openedition.org/methodos/205].

Laks, A., and Most, G. (2016). Early Greek Philosophy, Vol. 3, Pt. 2: Early Ionian Thinkers; Vol. 5: Western Greek Thinkers, Pt. 2; Vol. 6, Pt. 1: Later Ionian and Athenian Thinkers. Cambridge, MA.

Lloyd, G.E.R. (1972). Parmenides' Sexual Theories. A Reply to Mr Kember. JHS 92, pp. 178-179.

Long, A.A., ed. (1999). The Cambridge Companion to Early GreekPhilosophy. Cambridge. López-Ruiz, C. (2016). Cosmogonies and Theogonies, in S. Hornblower et alii, eds. OC, online. 
Louden, B. (1993). An Extended Narrative Pattern in the Odyssey. GRBS 34, pp. 5-33. [rev. repr. as ch. 1 in Louden 1999].

Louden, B. (1999). The Odyssey. Structure, Narration and Meaning. Baltimore.

Louden, B. (2006). The Iliad. Structure, Myth and Meaning. Baltimore.

Ma, J. (2016). Élites, élitisme et communauté dans la polis archaïque. Annales 71, pp. 633-658. [trans. Elites, elitism, and community in the archaic polis. Annales HSS 3, 2016, pp. 395-418].

Mansfeld, J. (1964). Die Offenbarung des Parmenides und die menschliche Welt. Assen.

Mansfeld, J. (1992). Heresiography in Context. Hippolytus' Elenchos as a Source for Greek Philosophy. Leiden.

Mansfeld, J. (1994). The Rhetoric in the P<r>oem of Parmenides. In: L. Bertelli and P.L. Donini, eds., Filosofia, politica, retorica. Intersezioni possibili, Milan, pp. 1-11.

Mansfeld, J. (1995). Insight by Hindsight. Intentional Unclarity in Presocratic Proems. BICS 40, pp. 225-232. [repr. in Mansfeld 2018a, pp. 40-51].

Mansfeld, J. (2005). Minima Parmenidea. Mnemosyne 58, pp.554-56o. [repr. in Mansfeld 2018a, pp. 177-184].

Mansfeld, J. (2011). Parmenides. In: J. Mansfeld and O. Primavesi, eds., Die Vorsokratiker, Griechisch / Deutsch, Stuttgart, pp. 290-341.

Mansfeld, J. (2015). Parmenides from Right to Left. Études platoniciennes 12, online https://doi.org/10.400o/etudesplatoniciennes.699. [repr. in Mansfeld 2018a, pp. 185-202].

Mansfeld, J. (2016). Melissus between Miletus and Elea. In: M. Pulpito, ed., Melissus between Miletus and Elea, Sankt Augustin, pp. 71-114.

Mansfeld, J. (2018a). Studies in Early Greek Philosophy. Leiden.

Mansfeld, J. (2018b). Parmenides on Sense Perception in Theophrastus and Elsewhere. In: Pulpito and Spangenberg eds., pp. 173-186. [also in Mansfeld 2018a, pp. 203-217].

Mansfeld, J. (2019). Il faut que vous soyez instruit de toutes choses... Études platoniciennes 15, https://doi.org/10.400o/etudesplatoniciennes.1458.

Mansfeld. J. (forthcoming). The End of the World in Ancient Philosophy. Eranos Jahrbuch.

Mansfeld, J., and Runia, D.T. eds. (2020). Aëtiana, Vol. 5.1-4: An Edition of the Reconstructed Text of the Placita with a Commentary and a Collection of Related Texts. Leiden. [abridged M-R].

Martin, R.P. (1983). Healing, Sacrifice and Battle. Amēchania and Related Concepts in Early Greek Poetry. Innsbruck.

McKirahan, R. (2009). Signs and Arguments in Parmenides B8. In: Curd and Graham, eds., pp. 189-229.

Meijer, P.A. (1984). Parmenides' fr. 1 of 'Hoe maak ik een mythe'. Lampas 17, pp. 142-161. Most, G.W. (1999). The Poetics of early Greek Philosophy. In: Long, ed., pp. 332-362. 
Mourelatos, A.P.D. (2008). The Route of Parmenides. rev. and expand. ed. Las Vegas. [1st ed. 1970].

Nehamas, A. (1981). On Parmenides' Three Ways of Inquiry. Deucalion 33-34, pp. 97-111. Nightingale, A.W. (2007). The Philosopher in Archaic Greek Culture. In: Shapiro, ed., pp. 169-198.

Northrup, M.D. (1980). Hesiodic Personifications in Parmenides A37. TAPA 110, pp. 223-232.

O’Brien, D. (1968). Derived Light and Eclipses in the Fifth Century. JHS 88, pp. 114-127.

Osborne, C. (1998). Was Verse the Default Form for Presocratic Philosophy? In: C. Atherton, ed., Form and Content in Didactic Poetry, Bari, pp. 23-35.

van Otterlo, W.A.A. (1944). Eine merkwürdige Kompositionsform der älteren griechischen Literatur. Mnemosyne 12, pp. 192-207.

Papousado, D. (1999). Der Schnitt zwischen dem Idealen und dem Realen. Schopenhauers Erkenntnisphilosophie. Bonn. (non vidi).

Passmore, J. (1961). Philosophical Reasoning. London.

Piano, V. (2016). Il papiro di Derveni tra religione e filosofia. Florence.

Popper, K. (1992). How the Moon Might Throw Some of Her Light upon the Two Ways of Parmenides. CQ 42, pp. 12-19. [rev. repr. in: A.F. Petersen and J. Mejer, eds., The World of Parmenides. Essays on the Presocratic Enlightenment, Abindon 2012, pp. 68-78].

Primavesi, O. (2011). Der Weg zur Offenbarung. Über Licht und Nacht im Proömium des Parmenides. In: G. Radke-Ullmann and A. Schmitt, eds., Anschaulichkeit in Kunst und Literatur. Wege bildlicher Visualisierung in der europäischen Geschichte, Berlin, pp. 181-232. [trans. Le chemin vers la révélation: lumière et nuit dans le proème de Parménide. Philos Ant 13, 2013, pp. 37-81].

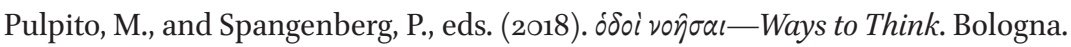

Reinhardt. K. (1916). Parmenides und die Geschichte der griechischen Philosophie. Bonn. [repr. Francfort 2012; trans. of selected passages entitled The Relation between the Two Parts of Parmenides' Poem. In: Mourelatos, A.P.D. ed., The Presocratics. A Collection of Critical Essays, Princeton 1993, pp. 293-311].

Rossetti, L. (2010). La structure du poème de Parménide. Philos Ant 10, pp. 187-226.

Rossetti, L. (2017). Un altro Parmenide, Vol. 1: Il sapere peri physeos. Parmenide e l'irrazionale; Vol. 2: Luna, antipodi, sessualità, logica. Bologna.

Runia, D.T. (2019). Ancient Doxography. Oxford Bibliographies Online. https://www .oxfordbibliographies.com/view/document/obo-978o195389661/obo-9780195389661 $-0227 . x \mathrm{ml}$.

Santoro, F. (2013). Allégories et rondeaux philosophiques dans le Poème de la Nature d'Empédocle. Xẃpa, Revue d'études anciennes et médiévales 11, pp. 183-200.

Sassi, M.M. (2013). La logique de l'eoikos et ses transformations. Xénophane, Parménide, Platon. $A C_{13}$, pp. 13-35.

Sassi, M.M. (2015). Parmenides and Empedocles on krasis and Knowledge. Apeiron 49, pp. $45^{1-469 .}$ 
Schiesaro, A., Mitsis, P., and Strauss Clay, J., eds. (1994). Mega nepios. Il destinatario nell'epos didascalico - The Addressee in the Didactic Epic. Pisa.

Schöne, A. (1994). Johann Wolfgang Goethe, Faust. Kommentare. Frankfurt.

Schopenhauer, A. (1877). Parerga und Paralipomena. Kleine philosophische Schriften, Vol. 1. 3rd ed. Leipzig; contains Aphorismen zur Lebensweisheit, pp. 329-530. Engl. trans. by Saunders, T.B. 189o, The Wisdom of Life. Being the First Part of Aphorismen Zur Lebensweisheit. Online.

Scodel, R. (2011). Euripides, the Derveni Papyrus and the Smoke of Many Writings. In: A. Lardinois, J. Blok, and M.G.M. van der Poel, eds., Sacred Words. Orality, Literacy and Religion, Leiden, pp. 79-98.

Sedley, D. (1999). Parmenides and Melissus. In: Long, ed., pp. 115-133.

Shapiro, H.A. (1993). Personifications in Greek Art. Kilchberg/Zürich.

Shapiro, H.A., ed. (2007). The Cambridge Companion to Archaic Greece. Cambridge.

Spoerri, W. (1959). Späthellenistische Berichte über Welt, Kultur und Götter. Basel.

Strauss Clay, J. (2015). Commencing Cosmogony and the Rhetoric of Poetic Authority. In: P. Derron, ed., Cosmogonies et cosmologies dans la littérature antique, Vandœuvres, pp. 105-137.

Tarán, L. (1965), Parmenides. A Text with Translation, Commentary and Critical Essays. Princeton.

Toohey, P. (1996). Epic Lessons. An Introduction to Ancient Didactic Poetry. London.

Tor, S. (2017). Mortal and Divine in Early Greek Epistemology. A Study of Hesiod, Xenophanes and Parmenides. Cambridge.

Tor, S. (2020). Parmenides on the Soul. In: H. Bartoš and C.G. King, eds., Heat, Pneuma and Soul in Greek Philosophy and Science, Cambridge, pp. 61-79.

Trépanier, S. (2010). Early Greek Theology. God as Nature and Natural Gods. In: J.N. Bremmer and A. Erskine, eds., The Gods of Ancient Greece. Identities and Transformations, Edinburgh, pp. 273-317.

Vesperini, P. (2015). La poésie didactique dans l'antiquité. Une invention des modernes. Anabases 21, pp. 25-38.

West, M.L. (2006). Towards a Chronology of Early Epic Poetry. In: Anderson and Haug, eds., pp. 224-241.

Wöhrle, G. (1993). War Parmenides ein schlechter Dichter? Oder: zur Form der Wissensvermittlung in der frühgriechischen Philosophie. In: W. Kullman and J. Althoff, eds., Vermittlung und Tradierung von Wissen in der griechischen Kultur, Tübingen, pp. 167-180.

Woodbury, L. (1958). Parmenides on Names. HSPh 63, pp. 145-16o. [repr. in: J.P. Anton and G.L. Kustas, eds., Essays in Ancient Greek Philosophy, Albany NY 1971, pp. 145-162 ].

Zeller, E., Mondolfo, R., and Reale, G. (2011). Gli Eleati. Milan. [repr. from La filosofia dei Greci nel suo sviluppo storico, Vol. 3: Eleati. Florence 1965]. 